\title{
Review
}

\section{Ozone oxidation for the alleviation of membrane fouling by natural organic matter: A review}

\author{
Steven Van Geluwe ${ }^{a, *}$, Leen Braeken ${ }^{a, b}$, Bart Van der Bruggen ${ }^{a}$ \\ ${ }^{a}$ Laboratory of Applied Physical Chemistry and Environmental Technology, Department of Chemical Engineering, K.U. Leuven, \\ W. de Croylaan 46, B-3001 Leuven (Heverlee), Belgium \\ ${ }^{\mathrm{b}}$ Department of Industrial Sciences and Technology, KHLim, Universitaire Campus Gebouw B, Bus 3, B-3590 Diepenbeek, Belgium
}

\section{A R T I C L E I N F O}

Article history:

Received 26 January 2011

Received in revised form

1 April 2011

Accepted 8 April 2011

Available online 15 April 2011

Keywords:

Humic acids

Hydrophobicity

Electrostatic interactions

Molecular mass

Aggregation

Hydrogen peroxide

\begin{abstract}
A B S T R A C T
Membrane fouling by natural organic matter is one of the main problems that slow down the application of membrane technology in water treatment. $\mathrm{O}_{3}$ is able to efficiently change the physico-chemical characteristics of natural organic matter in order to reduce membrane fouling. This paper presents the state-of-the-art knowledge of the reaction mechanisms between natural organic matter and molecular $\mathrm{O}_{3}$ or ${ }^{\circ} \mathrm{OH}$ radicals, together with an in-depth discussion of the interactions between natural organic matter and membranes that govern membrane fouling, inclusive the effect of $\mathrm{O}_{3}$ oxidation on it.
\end{abstract}

(c) 2011 Elsevier Ltd. All rights reserved.

\section{Contents}

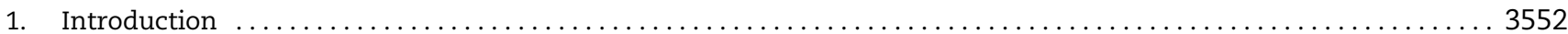

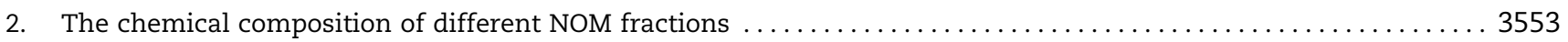

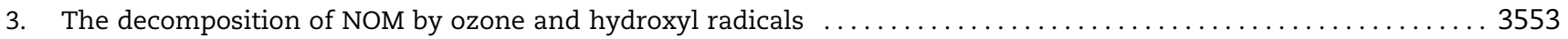

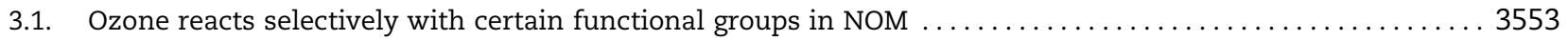

3.2. Which functional groups in the NOM can act as a promoter or inhibitor of $\mathrm{O}_{3}$ decomposition? ......... 3555

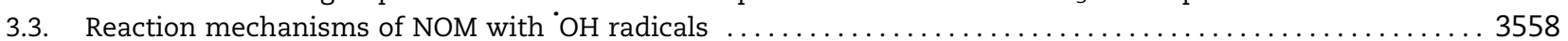

3.4. The addition of $\mathrm{H}_{2} \mathrm{O}_{2}$ slightly improves the mineralization of organic matter during ozonation .......... 3559

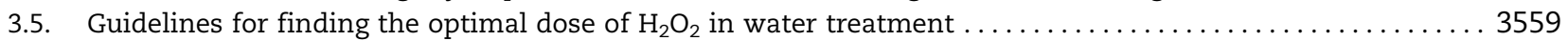

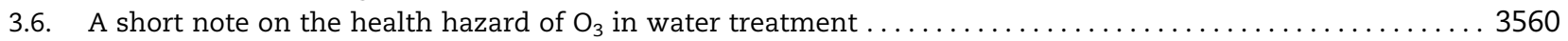

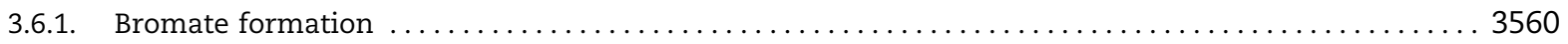

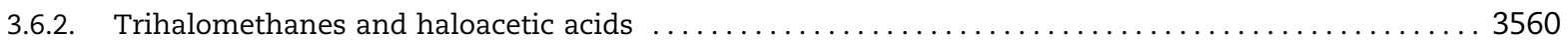

* Corresponding author. Tel.: +32 16322 341; fax: +32 16322991.

E-mail addresses: steven.vangeluwe@cit.kuleuven.be (S. Van Geluwe), leen.braeken@khlim.be (L. Braeken), bart.vanderbruggen@cit. kuleuven.be (B. Van der Bruggen).

0043-1354/\$ - see front matter @ 2011 Elsevier Ltd. All rights reserved.

doi:10.1016/j.watres.2011.04.016 


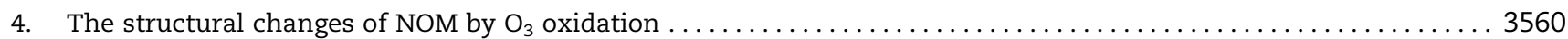

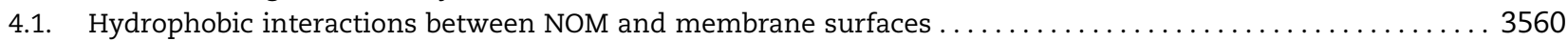

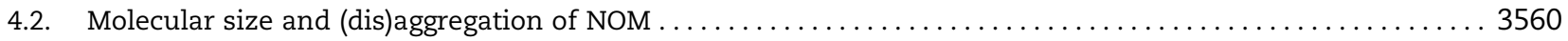

4.2.1. Results obtained by high-performance size exclusion chromatography (HPSEC) $\ldots \ldots \ldots \ldots \ldots \ldots 3560$

4.2.2. Aggregation of humic substances by calcium and magnesium $\ldots \ldots \ldots \ldots \ldots \ldots \ldots \ldots \ldots \ldots \ldots \ldots$

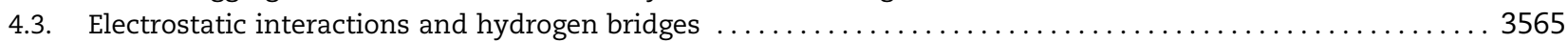

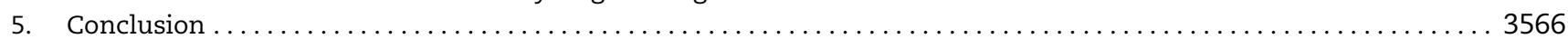

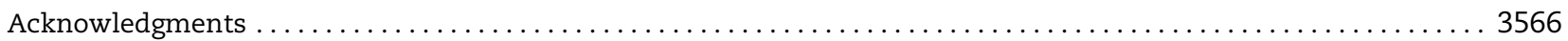

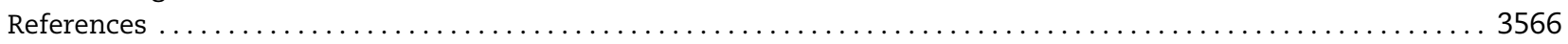

\begin{tabular}{|c|c|}
\hline \multicolumn{2}{|c|}{ Abbreviations } \\
\hline AOP & advanced oxidation process \\
\hline $\begin{array}{l}\mathrm{BOD}_{5} \\
\mathrm{COD}\end{array}$ & biological oxygen demand after 5 days \\
\hline COD & chemical oxygen demand \\
\hline DBP & disinfection by-product \\
\hline DOC & dissolved organic carbon \\
\hline FTIR & Fourier transform infrared \\
\hline HAA & haloacetic acid \\
\hline IEP & isoelectric point \\
\hline MF & microfiltration \\
\hline MWCO & molecular weight cut-off \\
\hline
\end{tabular}

$\begin{array}{ll}\text { NF } & \text { nanofiltration } \\ \text { NMR } & \text { nuclear magnetic resonance } \\ \text { NOM } & \text { natural organic matter } \\ \text { PVDF } & \text { polyvinylidene fluoride } \\ \text { RO } & \text { reverse osmosis } \\ \text { SBH } & \text { Staehelin, Bühler and Hoigné } \\ \text { THM } & \text { trihalomethane } \\ \text { TOC } & \text { total organic carbon } \\ \text { UF } & \text { ultrafiltration } \\ \text { USEPA } & \text { United States Environmental Protection Agency } \\ \text { UVA } & \text { absorbance (optical density) of UV irradiation }\end{array}$

\section{Introduction}

Membrane technology has become well established in water treatment, and the demand for membranes increases yearly by $8 \%$ (Leiknes, 2009). The most important type of membrane processes are pressure-driven, including microfiltration (MF), ultrafiltration (UF), nanofiltration (NF) and reverse osmosis (RO). Typical values of the main membrane characteristics, i.e. water permeability, operating pressure, pore size and retention characteristics for these four membrane types are listed in Table 1. Because of the large pores of the MF and UF membranes, the water flux is high while the transmembrane pressure is low. MF is used for the removal of suspended particles, turbidity and various micro-organisms (Yuan and Zydney, 1999), while UF removes viruses (van Voorthuizen et al., 2001), colloids and the high-molecular mass fraction of natural organic matter (NOM) as well (Siddiqui et al., 2000; Lee et al., 2005a; Kennedy et al., 2005). NF membranes have smaller pores, but still maintain a fairly high flux at a reasonable pressure. NF is very effective in the removal of the mediumand lower-molecular mass fraction of NOM (Siddiqui et al., 2000; Shon et al., 2004; Meylan et al., 2007; de la Rubia et al., 2008), and emerging micropollutants such as pesticides, pharmaceuticals and endocrine disrupting chemicals (Kimura et al., 2003; Nghiem et al., 2004; Yoon et al., 2006; Verliefde et al., 2007). The retention of inorganic ions by NF membranes is strongly dependent on the charge of the ions. The retention of divalent ions ranges between 50 and $100 \%$. It is much higher than the retention of monovalent ions, which is usually lower than $40 \%$, because of Donnan exclusion (de la Rubia et al., 2008; Ouyang et al., 2008). RO is commonly used for desalting brackish water and seawater, but operates under very high transmembrane pressures and a low permeate flux compared to the other pressure-driven membranes. However, RO shares about $45 \%$ of the global production capacity of desalinated water, because of its lower energy consumption compared to multistage flash evaporation (Darwish and Al-Najem, 2000; Eltawil et al., 2009).

In spite of the excellent retention characteristics of membrane filtration in water treatment, there are still problems that slow down its growth. The best known problem is fouling of the membrane, which results in a reduction in water flux, and thus leads to higher operating costs. Over time, fouling and subsequent cleaning of the membranes causes deterioration of membrane materials, resulting in a compromised permeate water quality and ultimately, a shorter membrane lifetime (Košutić and Kunst, 2002; Seidel and Elimelech, 2002; Al-Amoudi and Lovitt, 2007). Membrane fouling is usually minimized by an excessive pretreatment or else a very conservative membrane flux needs to be used. Consequently, the capital cost is high, which makes membrane filtration less competitive against conventional water treatment technologies (such as coagulation or activated carbon) in certain cases (Pianta et al., 2000).

The emerging use of $\mathrm{O}_{3}$ oxidation in water treatment offers new opportunities, because $\mathrm{O}_{3}$ is able to decompose certain membrane foulants very efficiently. The present paper is a critical review of literature concerning the fouling potential of NOM in water purification and the use of $\mathrm{O}_{3}$ oxidation for the alleviation of membrane fouling by NOM. The effect of $\mathrm{O}_{3}$ oxidation on membrane fouling is difficult to predict due to the complex nature of NOM, the strong variability of the NOM characteristics and the water matrix with location, season and weather (Lowe and Hossain, 2008), and the major effect of the water matrix on the conformation of NOM and the decomposition of $\mathrm{O}_{3}$. This review paper presents the reaction 
Table 1 - Comparison between the four pressure-driven membrane processes with respect to permeability, applied pressure, pore size and rejection characteristics.

\begin{tabular}{cccc} 
Microfiltration (MF) & Ultrafiltration (UF) & Nanofiltration (NF) & Reverse osmosis (RO) \\
\hline$>500$ & $100-500$ & $15-150$ & $0.5-15$ \\
$10-100$ & $100-500$ & $500-2000$ & $2000-4000$ \\
$100-10,000$ & $2-100$ & $0.1-2$ & $<1$ \\
& $1000-100,000$ & $150-1000$ & \\
+ & & & + \\
- & + & + & + \\
- & - & + & + \\
- & - & $-/+$ & + \\
- & - & + & + \\
\hline
\end{tabular}

mechanisms and its products when NOM solutions are treated by $\mathrm{O}_{3}$ or $\mathrm{O}_{3}+\mathrm{H}_{2} \mathrm{O}_{2}$, and the various interactions that exist between NOM components and the membrane surface. The relation between the complex fouling behavior of NOM, before and after its reaction with $\mathrm{O}_{3}$, is discussed in a systematic and detailed way, in order to better understand the mechanisms behind the fouling reduction in water treatment by $\mathrm{O}_{3}$ treatment.

\section{The chemical composition of different NOM fractions}

NOM is a complex heterogeneous mixture of organic material, such as humic substances, polysaccharides, aminosugars, proteins, peptides, lipids, small hydrophilic acids, and others (Frimmel et al., 2002). In a first approach to separate the different components in NOM, it is divided into two major classes. The first class, i.e. autochthonous NOM, is derived from extracellular macromolecules of micro-organisms in the water body and carbon fixation by algae and aquatic plants. The second class, allochthonous NOM, is derived from the decay of plant and animal residues in the watershed (Frimmel et al., 2002). It is usually referred to as humic substances, and this term will be used in the remaining text.

Although the correct chemical structure of humic substances still remains unknown, they consist of a skeleton of alkyl and aromatic units, cross-linked by a variety of functional groups. Humic substances are high in aromatic carbon and have a negative charge. This charge is primarily contributed by their three main functional groups, namely carboxylic acids, methoxyl carbonyls and phenolic functional groups (Thurman, 1986). The chemical properties of humic substances are succinctly explained by McDonald et al. (2004) and Sutzkover-Gutman et al. (2010). The humic substances present in natural waters are traditionally divided into two categories, namely humic and fulvic acids. Humic acids have a higher molecular mass (2000-5000 $\mathrm{g} \mathrm{mol}^{-1}$ ) than fulvic acids (500-2000 $\mathrm{g} \mathrm{mol}^{-1}$ ) (Her et al., 2003). They have a lower oxygen content and are more hydrophobic than fulvic acids (Thurman, 1986).

The knowledge of the structural chemistry of humic substances is somewhat like that of proteins in the middle of the last century. Although the main building blocks are known, there are no conclusive studies about the long-range conformational structure of humic substances. This is probably because of the difficulty of obtaining reliable structural data, due to the size and number of stereochemical isomers (Jansen et al., 1996). In addition, the conformation of humic substances may vary significantly due to changes in $\mathrm{pH}$ (humic substances are highly deprotonated is most aquatic environments), cation concentration (humic substances form strong complexes with metals and other cations) and the great stabilization effect on the electrostatic energy by the presence of water molecules (Kubicki and Apitz, 1999). Therefore, the complexity of humic substances in its natural environment is too high for the application of modeling techniques on an atomic scale.

Autochthonous NOM includes a large number of relatively simple compounds of known structures: carbohydrates, aminosugars, proteins, peptides, small organic acids, etc. The main functional groups in autochthonous NOM are carboxylic acids, alcohols and amines, which make these compounds hydrophilic, in contrast to the more hydrophobic humic substances. The molecular mass of these hydrophilic compounds shows a great variety. The simple organic molecules have a molecular mass of a few $100 \mathrm{~g} \mathrm{~mol}^{-1}$, and thus have an apparently smaller molecular size than humic substances, while the biopolymers, such as polysaccharides and proteins, have a molecular mass between 10,000 and $30,000 \mathrm{~g} \mathrm{~mol}^{-1}$ (Lee et al., 2004), which is about one order of magnitude higher than the molecular mass of humic substances. Polysaccharides present in surface water have a diameter in the range between 2 and $20 \mathrm{~nm}$. They have a linear molecular structure and can be hundreds of times longer than wide and can be branched (Leppard, 1997).

\section{The decomposition of NOM by ozone and hydroxyl radicals}

\subsection{Ozone reacts selectively with certain functional groups in NOM}

$\mathrm{O}_{3}$ is a powerful oxidant and its high reactivity can be attributed to the electronic configuration of this molecule. The $\mathrm{O}_{3}$ molecule represents a hybrid, formed by the two possible resonance structures shown in Fig. 1. The positive formal charges on the central oxygen atom in both resonance structures explains the electrophilic character of $\mathrm{O}_{3}$. 


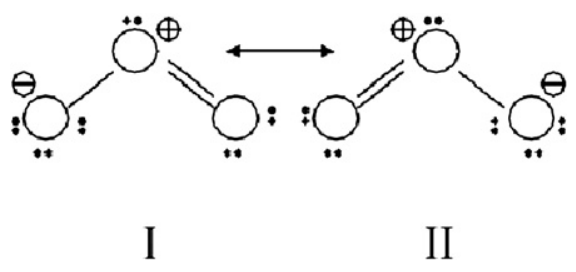

Fig. 1 - Resonance forms of the $\mathrm{O}_{3}$ molecule. Adapted from Beltrán (2004).

Conversely, the excess negative charge present in one of the terminal atoms imparts a nucleophilic character to $\mathrm{O}_{3}$. These properties make $\mathrm{O}_{3}$ an extremely reactive compound (Beltrán, 2004).

The electrophilic character of $\mathrm{O}_{3}$ accounts for the very fast reaction of $\mathrm{O}_{3}$ with unsaturated bonds (von Gunten, 2003a). The fast reaction of $\mathrm{O}_{3}$ with double bonds and aromatic rings present in NOM molecules, is manifested by a sharp decrease of the optical density at $254 \mathrm{~nm}\left(\mathrm{UVA}_{254}\right)$ during ozonation. For instance, Song et al. (2010) reported a $\mathrm{UVA}_{254}$ reduction of $71 \%$ in surface water treatment, at $\mathrm{a} \mathrm{O}_{3}$ dosage of $3.0 \mathrm{mg} \mathrm{L}^{-1}$ (oxidation time: $10 \mathrm{~min}$ ). Wang and Pai (2001) reported a reduction of $40 \%$ for biologically treated wastewater effluents, and Lee et al. (2009) observed a reduction of $55 \%$ for $\mathrm{RO}$ concentrates in wastewater reclamation, at the same $\mathrm{O}_{3}$ dosage and oxidation time. Although $\mathrm{O}_{3}$ oxidation is able to efficiently remove unsaturated bonds, it shows only a minor dissolved organic carbon (DOC) removal under acceptable economic conditions. Typical reductions of DOC achieved by ozonation in drinking water plants, with $\mathrm{O}_{3}$ doses between 2 and $5 \mathrm{mg} \mathrm{L}^{-1}$, is only about 10-20\% (Can and Gurol, 2003). The DOC removal in the experiments of Song et al. (2010) was approximately $10 \%$.
Wang and Pai (2001) reported 15\% DOC removal, while Lee et al. (2009) observed 5\% DOC removal, for the same $\mathrm{O}_{3}$ dosage and oxidation time as mentioned above.

von Gunten (2003a) reports that $\mathrm{O}_{3}$ preferentially reacts with unsaturated bonds to oxygenated saturated functional groups, such as aldehydic, ketonic and especially carboxylic groups. This can be demonstrated by the results of different spectroscopic techniques. Nuclear magnetic resonance (NMR) spectroscopy by Westerhoff et al. (1999), used for investigating the oxidation of surface waters by $\mathrm{O}_{3}$, found a depletion of aromatic against aliphatic moieties. The $\mathrm{O}_{3}$ consumption was positively correlated with aromatic carbon content, especially electron enriched aromatics, and inversely correlated with aliphatic carbon content. Fluorescence spectra of NOM solutions, before and after $\mathrm{O}_{3}$ oxidation (Świetlik and Sikorska, 2004; Zhang et al., 2008), revealed a reduction of the number of aromatic rings and conjugated bonds, and the decomposition of condensed aromatic moieties to smaller molecules. The number of electron withdrawing groups, such as carboxyl, carbonyl, hydroxyl, alkoxyl and amino groups, increased during ozonation. Mass spectrometry analysis of Suwannee River fulvic acids, by These and Reemtsma (2005), showed that $\mathrm{O}_{3}$ removes preferentially molecules with a low oxidation state (low $\mathrm{O} / \mathrm{C}$ ratio) and a high degree of unsaturation (low H/C ratio). They also observed that molecules with a more extended carbon skeleton and less carboxylate substituents showed higher reactivity, whereas some highly unsaturated molecules did not show measurable removal up to a specific $\mathrm{O}_{3}$ dose of $2.5 \mathrm{mg}$ per $\mathrm{mg}$ DOC. The reaction products were characterized by a very high number of carboxylate groups, i.e. the $\mathrm{O} / \mathrm{C}$ ratio increased from 0.2 to 0.7 .

Ozonation products can generally contain alcoholic, carbonyl and carboxyl groups (von Gunten, 2003a). The main reaction products after ozonation mainly consist of shortchain $(<\mathrm{C} 5)$ carboxylic acids, such as formic, acetic and particularly oxalic acid, and aldehydes, such as formaldehyde,

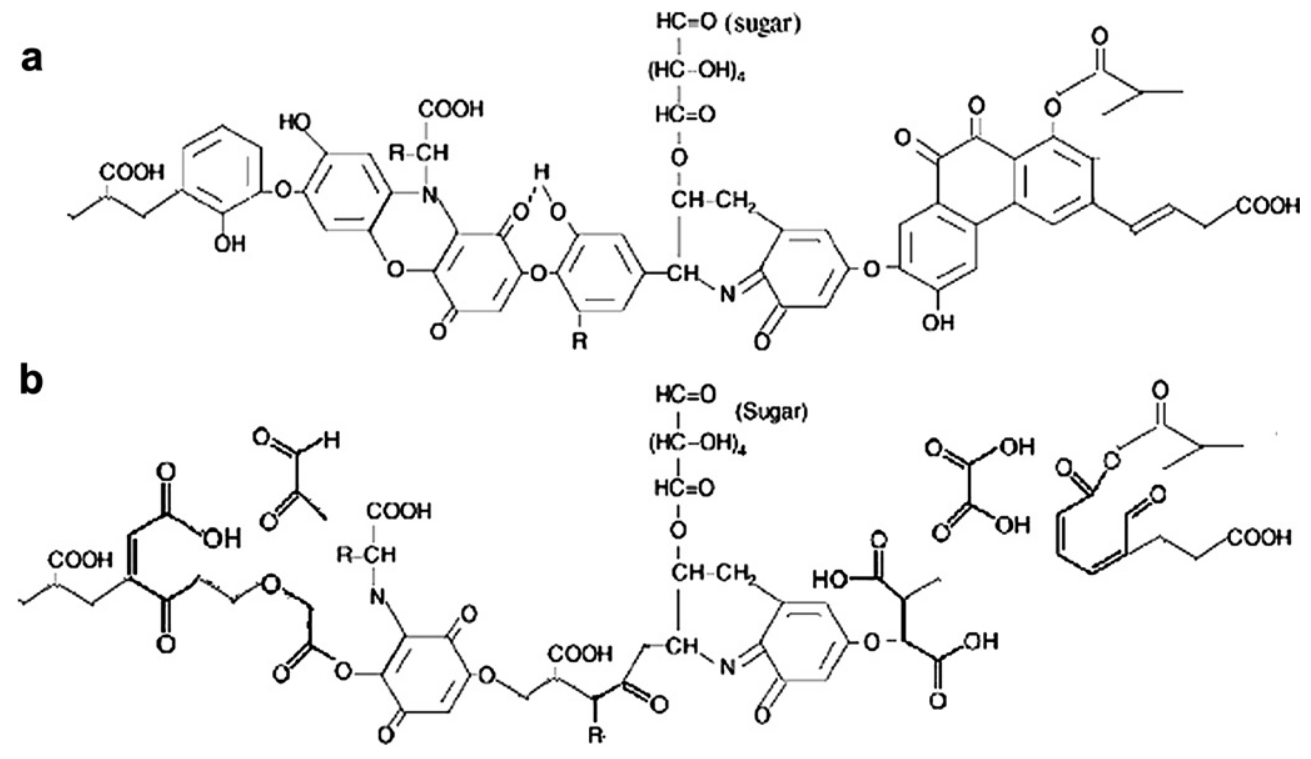

Fig. 2 - A hypothetical structure of humic substances (a) before and (b) after $\mathrm{O}_{3}$ oxidation. $\mathrm{O}_{3}$ reacts selectively with electronrich sites (double bonds, aromatic rings) by cycloaddition and electrophilic substitution, and can even breakup aromatic rings. $\mathrm{O}_{3}$ transforms them to carbonyl and carboxyl groups, which adsorb less on hydrophobic membranes. Adapted from Song et al. (2004). 
acetaldehyde, glyoxal and methylglyoxal (Xiong et al., 1992; Nawrocki et al., 2003; Hammes et al., 2006; Wert et al., 2007). Oxalic acid is formed mainly by the destruction of aromatic rings by $\mathrm{O}_{3}$ (Kusakabe et al., 1990). The amounts of carboxylic acids generated upon ozonation are usually much higher, i.e. approximately one order of magnitude, than those of aldehydes and ketones (Nawrocki et al., 2003; Xie, 2004). Can and Gurol (2003) observed that a high $\mathrm{O}_{3}$ dose results in a decline in the concentration of aldehydes, due to their oxidation to carboxylic acids. The saturated reaction products accumulate in the solution and are not mineralized, even after long oxidation times (Oh et al., 2003; von Gunten, 2003a; Van Geluwe et al., 2010, Van Geluwe et al., in press). The inefficient reaction between $\mathrm{O}_{3}$ and the saturated reaction products can be demonstrated by the low rate constants between $\mathrm{O}_{3}$ and these molecules, which are given in Table 2. With the exception of formate, which reacts relatively well with $\mathrm{O}_{3}$, the rate constants range between $10^{-5}$ and $10^{1} \mathrm{M}^{-1} \mathrm{~s}^{-1}$, while rate constants with olefins and aromatic rings can reach values of $10^{6}$ and $10^{9} \mathrm{M}^{-1} \mathrm{~s}^{-1}$, respectively (Williamson and Cvetanovic, 1970; Hoigné and Bader, 1983b). This explains why $\mathrm{O}_{3}$ oxidation can only achieve a small DOC removal, as mentioned above.

The vast abundance of unsaturated bonds in humic substances facilitates the efficient decomposition of these compounds by $\mathrm{O}_{3}$ (Van Geluwe et al., 2009; Van Geluwe et al., 2010). The unsaturated bonds in these molecules are transformed to oxygenated saturated bonds. This is schematically represented in Fig. 2, where a model structure of a humic acid molecule is drawn, before and after $\mathrm{O}_{3}$ oxidation. The decomposition of proteins and polysaccharides by $\mathrm{O}_{3}$ was investigated by Cataldo (2003) and Wang et al. (1999), respectively. Cataldo (2003) found that only the aromatic amino acids tryptophan, tyrosine and phenylalanine are oxidized, as well as cysteine. The most reactive amino acid is tryptophan, followed by tyrosine while phenylalanine appears much less reactive toward $\mathrm{O}_{3}$. The reaction schemes between the former two amino acids and $\mathrm{O}_{3}$ are presented in Fig. 3. Histidine and methionine should probably react quite well with $\mathrm{O}_{3}$, but there is no direct spectral evidence for this claim. Concerning cysteine, $\mathrm{O}_{3}$ oxidates the thiol group, with the consequent formation of disulfide bonds and crosslinks between proteins containing cysteine residues (Fig. 3). The polyamide bond of the main chain of the protein is not degraded by the action of $\mathrm{O}_{3}$, even after prolonged exposure. However, $\mathrm{O}_{3}$ causes denaturation of proteins, i.e. introduces changes in their secondary and tertiary structure (Cataldo,

Table 2 - Rate constants (at $298 \mathrm{~K}$ ) for the reaction of $\mathrm{O}_{3}$ and $\mathrm{OH}$ radicals with the main reaction products after $\mathrm{O}_{3}$ oxidation of NOM. Sources: [a] Hoigné and Bader, 1983(a), [b] Hoigné and Bader, 1983(b), [c] Buxton et al., 1988.

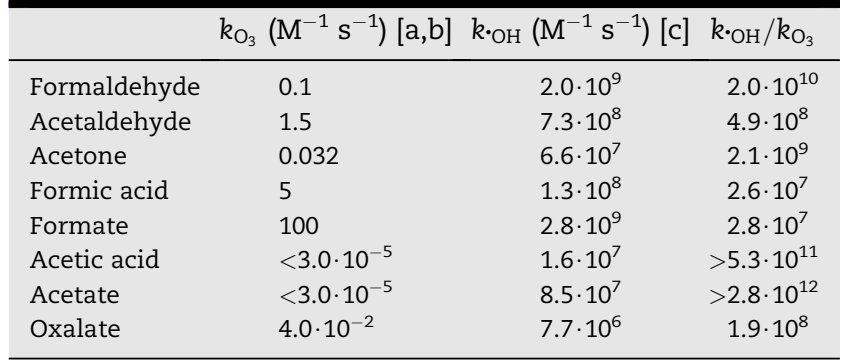

2003). Wang et al. (1999) showed that $\mathrm{O}_{3}$ depolymerizes polysaccharides by reacting with the glycosidic linkages in those molecules. It selectively oxidates $\beta$-D-glycosidic linkages to aldonic esters, as shown in Fig. 4. Ozonolysis proceeds under strong stereo-electric control. However, the oxidation of $\alpha$-D-glycosidic linkages during $\mathrm{O}_{3}$ oxidation is also possible, but slow, and is caused by several side reactions with radicals and acid hydrolysis.

\subsection{Which functional groups in the NOM can act as a promoter or inhibitor of $\mathrm{O}_{3}$ decomposition?}

$\mathrm{O}_{3}$ may react directly with dissolved substances in water, or it may decompose to form radical species, which themselves react with these substances. This corresponds to direct oxidation by molecular $\mathrm{O}_{3}$ and indirect oxidation, respectively. The most important radical species is the ${ }^{\circ} \mathrm{OH}$ radical, because of its high standard reduction potential $(2.80 \mathrm{~V})$, which is even higher than the standard reduction potential of $\mathrm{O}_{3}(2.07 \mathrm{~V})$ (Beltrán, 2004). In contrast to $\mathrm{O}_{3},{ }^{\circ} \mathrm{OH}$ is believed to be a non-selective oxidant, which reacts very fast with the vast majority of organic and inorganic compounds in water (von Gunten, 2003a).

The decomposition of $\mathrm{O}_{3}$ in pure water is well-described in literature. The SBH (Staehelin, Bühler, Hoigné) model is widely used for predicting the lifetime of $\mathrm{O}_{3}$ in natural waters (Beltrán, 2004). This model is represented in Fig. 5 and a brief discussion is given below.

The decomposition of $\mathrm{O}_{3}$ in water is a radical-type chain reaction, where various solutes can act as initiators, promoters or inhibitors (Staehelin and Hoigné, 1985).

Initiation step: The decomposition of $\mathrm{O}_{3}$ is initiated by $\mathrm{OH}^{-}$ ions (reaction 1), and this leads to the formation of one superoxide anion $\left(\mathrm{O}_{2}^{-}\right)$and one hydroperoxyl radical $\left({ }^{\circ} \mathrm{HO}_{2}\right)$, which are in an acid-base equilibrium $\left(\mathrm{pK}_{\mathrm{a}}=4.8\right)$ :

$\mathrm{O}_{3}+\mathrm{OH}^{-} \rightarrow \mathrm{O}_{2}^{-}+{ }^{\cdot} \mathrm{HO}_{2}\left(k=70 \mathrm{M}^{-1} \mathrm{~s}^{-1}\right)$

In addition, the reaction of unsaturated bonds in NOM with $\mathrm{O}_{3}$ can lead to the consumption of $\mathrm{O}_{3}$ (reaction 2), or the production of an ozonide ion radical $\left(\mathrm{O}_{3}^{-}\right)$by an electron transfer reaction (reaction 3):

$\mathrm{O}_{3}+\mathrm{NOM} \rightarrow \mathrm{NOM}_{\mathrm{OX}}$

$\mathrm{O}_{3}+\mathrm{NOM} \rightarrow \mathrm{NOM}^{+}+\mathrm{O}_{3}^{-}$

The direct reactions (2) and (3) between $\mathrm{O}_{3}$ and NOM are generally attributed to double bonds, electron-rich aromatic systems, amines and sulphides (von Gunten, 2003a). These direct reactions control the decomposition of $\mathrm{O}_{3}$ during the initial phase of ozonation ( $t<20 \mathrm{~s}$ ), in which very high amounts of ${ }^{\circ} \mathrm{OH}$ radicals are generated, i.e. the concentration $\mathrm{OH}$ is about $10^{-6}$ to $10^{-8}$ times the concentration of $\mathrm{O}_{3}$ (von Gunten, 2003a), and the presence of radical scavengers does not exert any significant effect on the $\mathrm{O}_{3}$ consumption (Xiong et al., 1991). During the second phase ( $t>20 \mathrm{~s}$ ), when the most reactive parts of NOM have already reacted with $\mathrm{O}_{3}$, the $\mathrm{O}_{3}$ decomposition is mostly controlled by radical chain reactions instead of direct reaction with $\mathrm{NOM}$, and the ${ }^{\circ} \mathrm{OH}$ concentration is about ten times lower than during the initial phase of ozonation (Buffle and von Gunten, 2006). 
<smiles>NC(CSSCC(N)C(=O)O)C(=O)O</smiles>

CYSTEINE<smiles>CSCC[C@H](N)C(=O)O</smiles>

METHIONINE

CYSTINE<smiles>CS(=O)(=O)CC[C@H](N)C(=O)O</smiles>

SULFONE<smiles>N[C@@H](Cc1c[nH]c2ccccc12)C(=O)O</smiles><smiles>CC(=O)c1cccc(C(=O)C[C@H](N)C(=O)O)c1N</smiles>

\section{TRYPTOPHAN}<smiles>N[C@@H](Cc1ccc(O)cc1)C(=O)O</smiles><smiles>N[C@@H](CC1=CC(=O)C(=O)C=C1)C(=O)O</smiles>

TYROSINE<smiles>N[C@@H](Cc1cnc[nH]1)C(=O)O</smiles><smiles>CC=O</smiles><smiles>N[C@@H](CC(=O)/N=C\NC=O)C(=O)O</smiles>

HISTIDINE

Fig. 3 - Mechanism for the reaction between amino acids and $\mathrm{O}_{3}$. Only the aromatic amino acids tryptophan, tyrosine and the much less reactive phenylalanine (not shown) are oxidized, as well as cysteine. Probably histidine and methionine should react quite well with $\mathrm{O}_{3}$, but there was no direct evidence of this. Concerning cysteine, $\mathrm{O}_{3}$ oxidates the thiol groups with the consequent formation of disulfide bonds. Adapted from Cataldo (2003). 


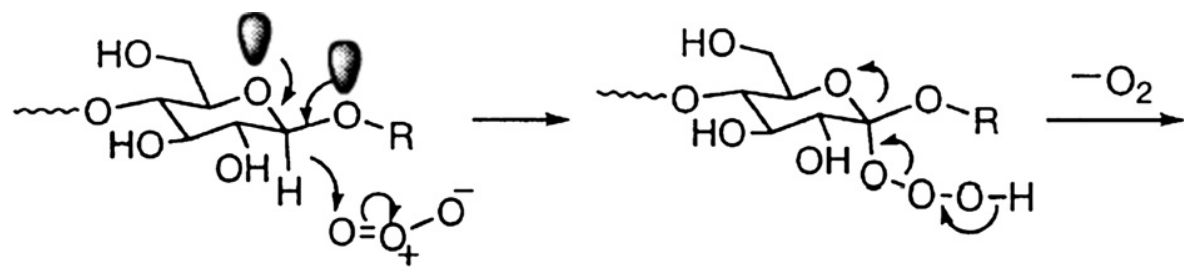

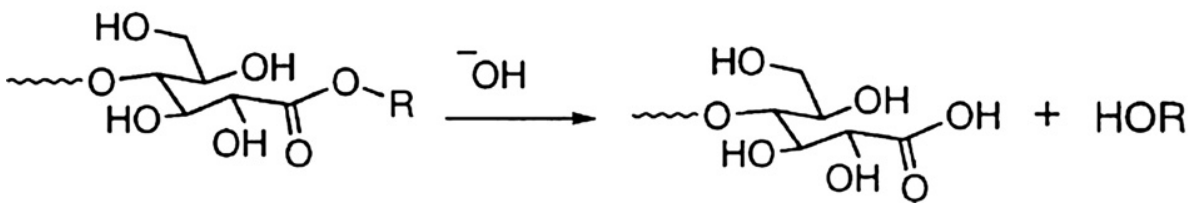

Fig. 4 - Mechanism for the reaction between polysaccharides and $\mathrm{O}_{3} . \mathrm{O}_{3}$ is very selective in cleaving $\beta$-D-aldosidic linkages. Ozonolysis proceeds only if the aldoside can assume a conformation in which the acetal function at the anomeric center has two of its lone-pair electron orbitals oriented trans-antiperiplanar (antiperiplanar: describing an angle between 150 and $210^{\circ}$ ) to the alkylidene $\mathrm{C}-\mathrm{H}$ bond (stereo-electric control). However, non-selective degradation is possible as well, due to the presence of ${ }^{\circ} \mathrm{OH}$ radicals and organic acids in the ozonated solution. Adapted from Wang et al. (1999).

Propagation step: ${ }^{\circ} \mathrm{O}_{2}^{-}$is a highly selective catalyst for the decomposition of $\mathrm{O}_{3}$ in water. The rate constant with which $\cdot \mathrm{O}_{2}^{-}$reacts with $\mathrm{O}_{3}$ molecules is very high and results in the formation of ${ }^{\circ} \mathrm{O}_{3}^{-}$:

$\mathrm{O}_{2}^{-}+\mathrm{O}_{3} \rightarrow \mathrm{O}_{3}^{-}+\mathrm{O}_{2}\left(k=1.6 \cdot 10^{9} \mathrm{M}^{-1} \mathrm{~s}^{-1}\right)$

$\cdot \mathrm{O}_{3}^{-}$decomposes upon protonation into ${ }^{\circ} \mathrm{OH}$ radicals:

$\mathrm{O}_{3}^{-}+\mathrm{H}^{+} \rightarrow \mathrm{HO}_{3} \quad\left(k=5 \cdot 10^{10} \mathrm{M}^{-1} \mathrm{~s}^{-1}\right)$

$\mathrm{HO}_{3} \rightarrow \cdot \mathrm{OH}+\mathrm{O}_{2}\left(k=1.4 \cdot 10^{5} \mathrm{M}^{-1} \mathrm{~s}^{-1}\right)$
Even in solutions where the DOC concentration is low, such as drinking water, the ${ }^{\circ} \mathrm{OH}$ radicals react with a solute before they encounter another radical (Staehelin and Hoigné, 1985). Typical rate constants for reactions of ${ }^{\circ} \mathrm{OH}$ radicals with organic solutes are in the range $10^{6}-10^{10} \mathrm{M}^{-1} \mathrm{~s}^{-1}$ (Buxton et al., 1988; Lal et al., 1988; Mao et al., 1991).

Some functional groups present in NOM are known to react with $\mathrm{OH}$, and this can lead to the formation of carboncentered radicals (see Fig. 5, reaction 7). The reaction of these carbon-centered radicals with $\mathrm{O}_{2}$ (see Fig. 5, reaction 8) subsequently leads to the elimination of ${ }^{\circ} \mathrm{HO}_{2} /{ }^{\circ} \mathrm{O}_{2}^{-}$in a base

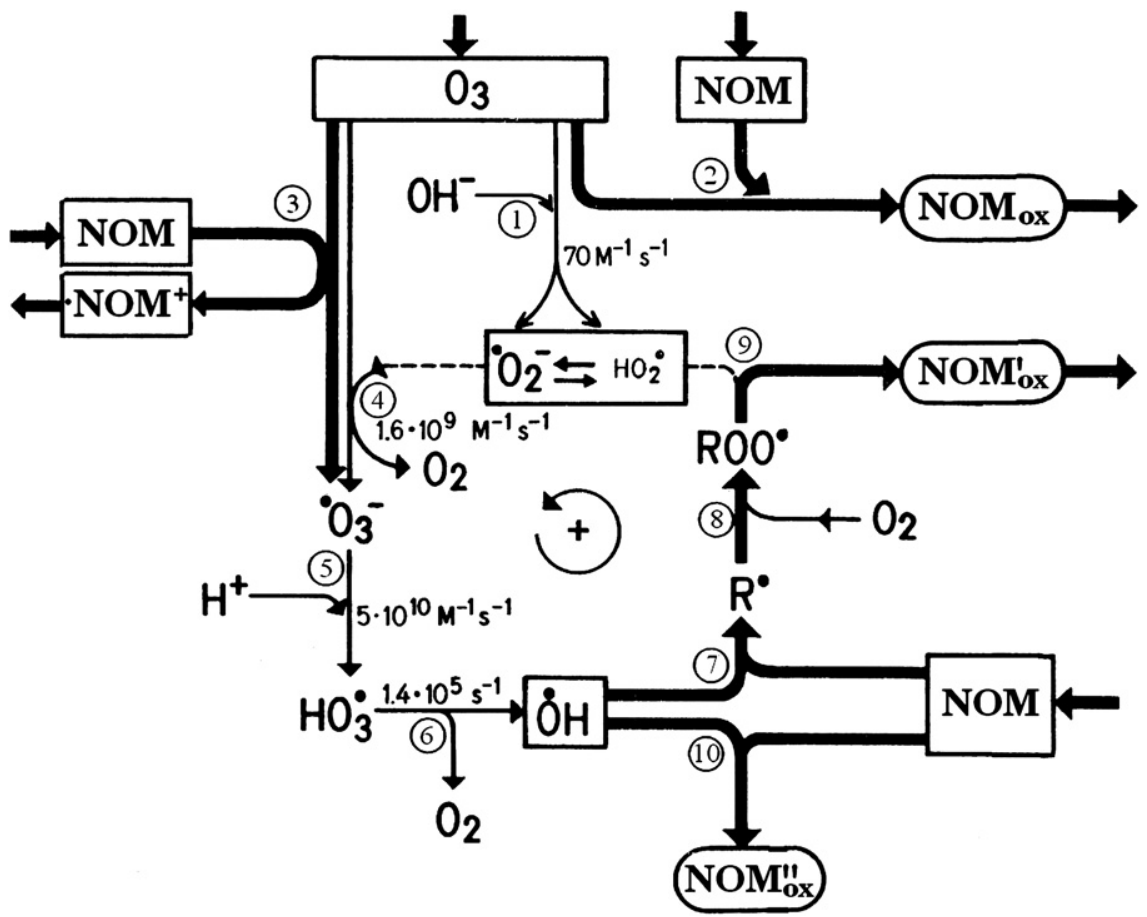

Fig. 5 - Reactions of aqueous $\mathrm{O}_{3}$ in the presence of NOM, which reacts with $\mathrm{O}_{3}$ or with $\mathrm{OH}$ radicals (scavenging or converting $\mathrm{OH}$ into $\mathrm{HO}_{2}$ ). Adapted from Staehelin and Hoigné (1985). 


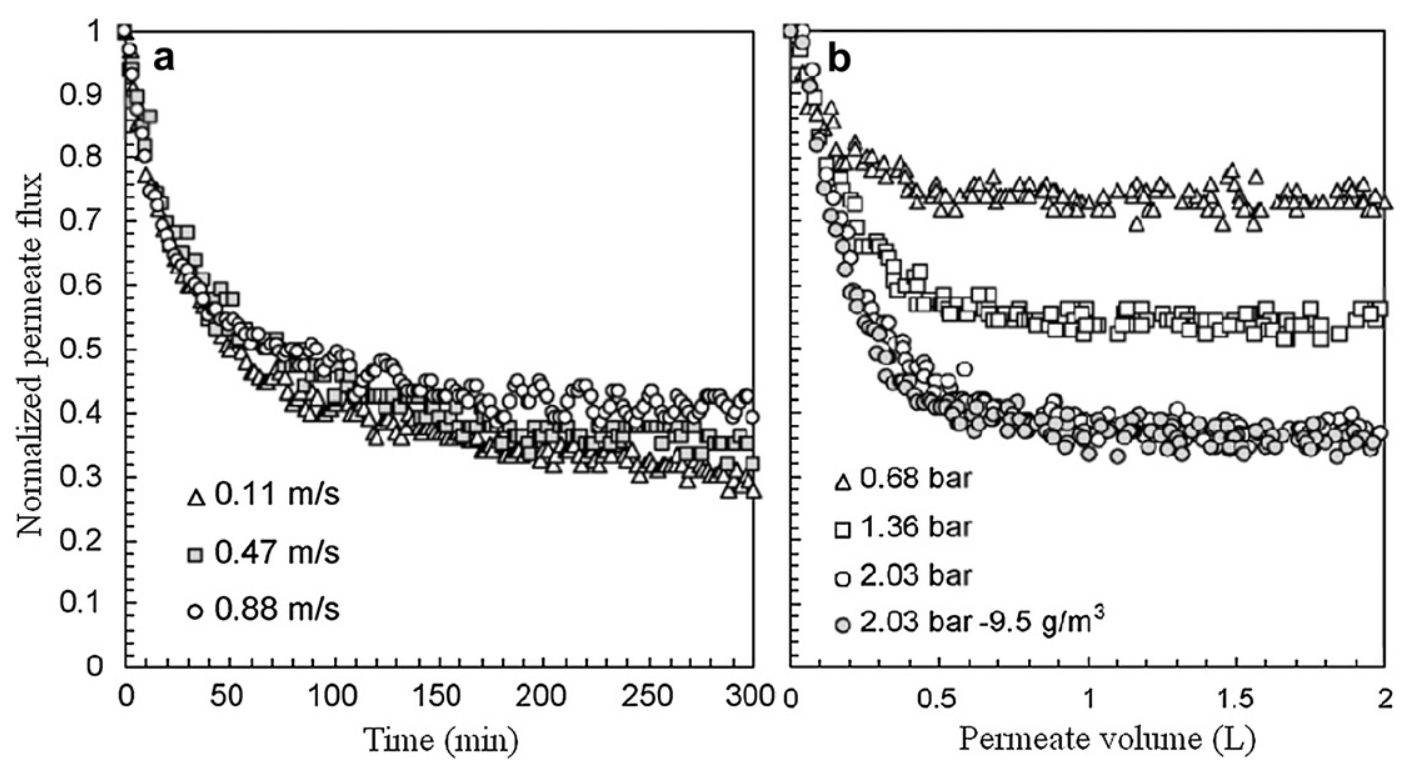

Fig. 6 - (a) Effect of cross-flow velocity on the permeate flux of a ceramic UF membrane treating surface water. The transmembrane pressure is $0.136 \mathrm{MPa}$ and the $\mathrm{O}_{3}$ concentration in the gas phase is $1.5 \mathrm{~g} \mathrm{~m}^{-3}$ (b) Effect of transmembrane pressure on permeate flux at an $\mathrm{O}_{3}$ concentration in the gas phase of $5.5 \mathrm{~g} \mathrm{~m}^{-3}$ (except if otherwise mentioned) and a crossflow velocity of $0.47 \mathrm{~m} \mathrm{~s}^{-1}$. Adapted from Kim et al. (2008).

catalyzed reaction (see Fig. 5, reaction 9). Due to the high selectivity of ${ }^{\circ} \mathrm{O}_{2}^{-}$for $\mathrm{O}_{3}$, the conversion of the less ozoneselective ${ }^{\circ} \mathrm{OH}$ radical into ${ }^{\circ} \mathrm{O}_{2}^{-}$promotes the chain reaction. This explains how certain functional groups of NOM act as promoters for the $\mathrm{O}_{3}$ decomposition (Staehelin and Hoigné, 1985).

Termination step: Many other solutes do not liberate ${ }^{\circ} \mathrm{O}_{2}^{-}$ radicals after reaction with ${ }^{\circ} \mathrm{OH}$ (see Fig. 5 , reaction 10 ). These substances are called inhibitors or radical scavengers.

The question that remains is "which functional groups of NOM promote the decomposition of $\mathrm{O}_{3}$, and which functional groups act as inhibitors?" Primary alcohols (such as methanol, glycol, glycerine, or present in glucose and other carbohydrates) promote the decomposition of $\mathrm{O}_{3}$, although their direct reaction with $\mathrm{O}_{3}$ is rather slow, due to the absence of unsaturated bonds (Staehelin and Hoigné, 1985). Aromatic rings can also be regarded as promoters for $\mathrm{O}_{3}$ decomposition, because the attack of $\mathrm{O}_{3}$ and ${ }^{\circ} \mathrm{OH}$ cleave aromatic rings into olefins, which immediately react with $\mathrm{O}_{3}$, with the subsequent formation of $\mathrm{H}_{2} \mathrm{O}_{2}$ (Pi et al., 2005). Glyoxalate can act both as a promoter and initiator (Staehelin and Hoigné, 1985). Alkyl groups and carboxylic acids (with the exception of formic acid, which is a promoter) are inhibitors (Staehelin and Hoigné, 1985). $\mathrm{OH}$ can also subtract a $\mathrm{H}$ atom from higher alkyl alcohols than methanol, such as tert-butyl alcohol, that is not in a position $\alpha$ to the $-\mathrm{OH}$ group. These reactions are not followed by the formation of ${ }^{\circ} \mathrm{O}_{2}^{-}$radicals, so these compounds act as scavengers. The relative importance of scavenging to promotion for aliphatic alcohols increases with the length of the alkyl chain in these compounds, relative to the amount of $\mathrm{H}$ atoms in a position $\alpha$ to the $-\mathrm{OH}$ group (Staehelin and Hoigné, 1985).

\subsection{Reaction mechanisms of NOM with ${ }^{\circ} \mathrm{OH}$ radicals}

Although the ${ }^{\circ} \mathrm{OH}$ radical is thought to be an unselective oxidant, organic molecules with unsaturated bonds react faster with ${ }^{\circ} \mathrm{OH}$ radicals than saturated $\mathrm{C}-\mathrm{C}$ bonds or $\mathrm{C}-\mathrm{H}$ bonds (Westerhoff et al., 1999). Reactions of ${ }^{\circ} \mathrm{OH}$ radicals with olefins and aromatic molecules occur at nearly diffusioncontrolled limits $\left(10^{10} \mathrm{M}^{-1} \mathrm{~s}^{-1}\right)$, whereas the slowest reaction rates with ${ }^{\circ} \mathrm{OH}$ radicals were observed for aliphatic polyhalogenated compounds such as haloacetic acids (HAA) and trihalomethanes (THM) $\left(10^{7}-10^{8} \mathrm{M}^{-1} \mathrm{~s}^{-1}\right)$ (Buxton et al., 1988; Lal et al., 1988; Mao et al., 1991). ${ }^{\circ} \mathrm{OH}$ can be regarded as an electrophilic oxidant like $\mathrm{O}_{3}$, because electron donating groups, such as hydroxyls and amines, enhance the reactivity of adjacent carbon bonds, while electron withdrawing groups, such as carboxyl groups, lessen its reactivity (Song et al., 2008). A few researchers determined the second rate constant of ${ }^{\circ} \mathrm{OH}$ reaction with NOM $\left(3.6 \cdot 10^{8} \mathrm{M}^{-1} \mathrm{~s}^{-1}\right.$ (Westerhoff et al., 1999)) or humic acids (1.9 $10^{7} \mathrm{M}^{-1} \mathrm{~s}^{-1}$ (Liao and Gurol, 1995), 8.1 . $10^{8} \mathrm{M}^{-1} \mathrm{~s}^{-1}$ (Westerhoff et al., 1999), 2.3-3.2 $10^{9} \mathrm{M}^{-1} \mathrm{~s}^{-1}$ (Goldstone et al., 2002)), at which the concentration of organic matter is expressed as mol C per liter.

Reactions of ${ }^{\circ} \mathrm{OH}$ radicals with organic compounds fall into two basic mechanisms, i.e. addition, generally to an aromatic ring (hydroxylation), or abstraction of a $\mathrm{H}$ atom. Both mechanisms can lead to the formation of low-molecular mass acids. Hydroxylation of aromatic moieties in NOM, followed by ring opening, can produce both mono- and dicarboxylic acids (Gopalan and Savage, 1994). Abstraction of $\mathrm{H}$ from an unsaturated $\mathrm{C}-\mathrm{C}$ bond leads to the formation of a carboncentered radical, followed by reaction with $\mathrm{O}_{2}$ to form a peroxyl radical, and subsequent decomposition to a carboxylic acid (Goldstone et al., 2002). 


\subsection{The addition of $\mathrm{H}_{2} \mathrm{O}_{2}$ slightly improves the mineralization of organic matter during ozonation}

The contribution of the radical pathway can strongly be enhanced by adding $\mathrm{H}_{2} \mathrm{O}_{2}$ to the solution. In this case, the main $\mathrm{O}_{3}$ decay path is the reaction between $\mathrm{O}_{3}$ and the conjugated base of $\mathrm{H}_{2} \mathrm{O}_{2}$, i.e. $\mathrm{HO}_{2}{ }^{-}\left(\mathrm{pK}_{\mathrm{a}}=2.24 \cdot 10^{-12}\right.$ (Paillard et al., 1988)), leading to a higher production rate of ${ }^{\circ} \mathrm{OH}$ radicals (Staehelin and Hoigné, 1982):

$\mathrm{O}_{3}+\mathrm{HO}_{2}^{-} \rightarrow \cdot \mathrm{OH}+{ }^{\circ} \mathrm{O}_{2}^{-}+\mathrm{O}_{2}\left(k=2.8 \cdot 10^{6} \mathrm{M}^{-1} \mathrm{~s}^{-1}\right)$

This leads to an advanced oxidation process (AOP). Indeed, in pure water systems, two ${ }^{\circ} \mathrm{OH}$ radicals are formed per three $\mathrm{O}_{3}$ molecules consumed, while in the presence of $\mathrm{H}_{2} \mathrm{O}_{2}$, one $\cdot \mathrm{OH}$ radical is formed per $\mathrm{O}_{3}$ molecule consumed (Acero and von Gunten, 2001). The main advantages of AOPs are the oxidation of ozone-resistant compounds. However, the higher formation rate of ${ }^{\circ} \mathrm{OH}$ is at the cost of a higher $\mathrm{O}_{3}$ consumption, i.e. the decomposition of $\mathrm{O}_{3}$ is accelerated in the presence of $\mathrm{H}_{2} \mathrm{O}_{2}$ at $\mathrm{pH}$ values higher than 5 (Staehelin and Hoigné, 1982). In addition, $\mathrm{OH}$ reacts rather unselective, and thus only a small fraction of these radicals reacts with the target pollutant, which severely reduces the efficiency of AOPs (von Gunten, 2003a).

Several researchers reported that $\mathrm{O}_{3}+\mathrm{H}_{2} \mathrm{O}_{2}$ systems remove DOC better, because of the ability of ${ }^{\circ} \mathrm{OH}$ radicals to react with the unsaturated reaction products formed during $\mathrm{O}_{3}$ oxidation. The effectiveness of ${ }^{\circ} \mathrm{OH}$ radicals for the mineralization of these compounds can be assessed by comparing the rate constants with $\mathrm{O}_{3}$ and ${ }^{\circ} \mathrm{OH}$ radicals (see Table 2). The rate constants for the reaction with ${ }^{\circ} \mathrm{OH}$ radicals is evidently higher than for the reaction with molecular $\mathrm{O}_{3}$. However, the concentration of ${ }^{\circ} \mathrm{OH}$ radicals is typically $10^{7}-10^{9}$ times lower than the dissolved $\mathrm{O}_{3}$ concentration (von Gunten, 2003a). If the proportion of the two rate constants is lower than $10^{8}$, an increase of the $\mathrm{OH}$ concentration will not be able to improve the decomposition of these saturated compounds. This proportion is calculated for each compound in the last column of Table 2, and it can be seen that it is higher than $10^{8}$ for all compounds, with the exception of formate, which already reacts relatively well with $\mathrm{O}_{3}$. Goldstone et al. (2002) reported that reactions between humic substances and ${ }^{\circ} \mathrm{OH}$ radicals produced $\mathrm{CO}_{2}$ with a high efficiency of $\sim 0.3 \mathrm{~mol} \mathrm{CO}_{2}$ per mole $\cdot \mathrm{OH}$. This efficiency remained approximately constant from the early phases of oxidation until complete mineralization of the DOC, and was not significantly altered within the range of $\mathrm{pH}$ values found in natural waters $(\mathrm{pH} 4-10)$. However, they reported that the $\mathrm{CO}_{2}$ production from ${ }^{\circ} \mathrm{OH}$ reaction with lowmolecular mass acids is an insignificant fraction of the overall $\mathrm{CO}_{2}$ formation rate, indicating that most of the mineralization of humic substances does not occur via low-molecular mass acid intermediates.

Acero and von Gunten (2001) reported that, when the organic matter content in the water is low $\left(<1 \mathrm{mg} \mathrm{L}^{-1} \mathrm{DOC}\right)$, the addition of $\mathrm{H}_{2} \mathrm{O}_{2}$ considerably enhances the oxidation capacity by ${ }^{\circ} \mathrm{OH}$ radicals. However, if the NOM concentration in natural waters is higher than $3 \mathrm{mg} \mathrm{L}^{-1} \mathrm{DOC}, \mathrm{O}_{3}$ decomposition is controlled by the promoting or inhibiting effect of certain functional groups in the DOC on the $\mathrm{O}_{3}$ decomposition. Therefore, the effect of
$\mathrm{H}_{2} \mathrm{O}_{2}$ addition in order to raise the ${ }^{\circ} \mathrm{OH}$ concentration, will be negligible in that case. This was also observed by the following researchers, who observed that $\mathrm{O}_{3}+\mathrm{H}_{2} \mathrm{O}_{2}$ performed well, but only slightly better than pure $\mathrm{O}_{3}$ oxidation. Irabelli et al. (2008) reported for surface water (DOC $>3 \mathrm{mg} \mathrm{L}^{-1}$ ) a DOC removal of $61 \%$ by $\mathrm{O}_{3}+\mathrm{H}_{2} \mathrm{O}_{2}$ (0.7 $\mathrm{mg} \mathrm{H}_{2} \mathrm{O}_{2}$ was added prior to oxidation) compared to $53 \%$ by $\mathrm{O}_{3}\left(\mathrm{O}_{3}\right.$ dosage: $2.0 \mathrm{mg} \mathrm{L}^{-1}$, reaction time: $13.2 \mathrm{~min})$. Van Geluwe et al. (2010) found that the continuous addition of $\mathrm{H}_{2} \mathrm{O}_{2}$ between 10 and 30 min oxidation time $(0.25 \mathrm{~mol}$ $\mathrm{H}_{2} \mathrm{O}_{2}$ per mole $\mathrm{O}_{3}$ ), could enhance the removal of UV absorbing compounds at $280 \mathrm{~nm}$, from $42 \%$ (if no $\mathrm{H}_{2} \mathrm{O}_{2}$ was added) to $54 \%$, for the treatment of humic acid solutions. If the same experimental conditions were applied to NF concentrates, obtained after filtration of surface water, a reduction of $74 \%$ could be achieved by $\mathrm{O}_{3}+\mathrm{H}_{2} \mathrm{O}_{2}$, compared to $68 \%$ by $\mathrm{O}_{3}$ (Van Geluwe et al., in press).

\subsection{Guidelines for finding the optimal dose of $\mathrm{H}_{2} \mathrm{O}_{2}$ in water treatment}

The dosage of $\mathrm{H}_{2} \mathrm{O}_{2}$ has a significant effect on the mineralization of organic compounds. There exists an optimal $\mathrm{H}_{2} \mathrm{O}_{2}$ dosage because this compound not only acts as a generator of $\cdot \mathrm{OH}$ radicals, but also as a scavenger of ${ }^{\circ} \mathrm{OH}$ radicals at high $\mathrm{H}_{2} \mathrm{O}_{2}$ concentrations. This is attributed to the formation of much less powerful $\mathrm{HO}_{2}$ radicals by the reaction between $\mathrm{H}_{2} \mathrm{O}_{2}$ and ${ }^{\circ} \mathrm{OH}$ (reaction 8), and the subsequent reaction of $\mathrm{HO}_{2}^{\circ}$ with ${ }^{\circ} \mathrm{OH}$ (reactions 9 and 10) (Weinstein and Bielski, 1979; Buxton et al., 1988):

$$
\begin{aligned}
& \mathrm{H}_{2} \mathrm{O}_{2}+{ }^{\circ} \mathrm{OH} \rightarrow \mathrm{H}_{2} \mathrm{O}+\mathrm{HO}_{2}^{\cdot} \quad\left(k=2.7 \cdot 10^{7} \mathrm{M}^{-1} \mathrm{~s}^{-1}\right) \\
& \mathrm{HO}_{2}^{\cdot}+{ }^{\circ} \mathrm{OH} \rightarrow \mathrm{H}_{2} \mathrm{O}+\mathrm{O}_{2} \quad\left(k=6.0 \cdot 10^{9} \mathrm{M}^{-1} \mathrm{~s}^{-1}\right) \\
& 2 \mathrm{HO}_{2}^{\cdot} \quad \rightarrow \mathrm{H}_{2} \mathrm{O}_{2}+\mathrm{O}_{2} \quad\left(k=7.6 \cdot 10^{5} \mathrm{M}^{-1} \mathrm{~s}^{-1}\right)
\end{aligned}
$$

Multiple additions of $\mathrm{H}_{2} \mathrm{O}_{2}$ at different stages is better for DOC removal than a single addition of $\mathrm{H}_{2} \mathrm{O}_{2}$ at the inlet of the reactor only (Kosaka et al., 2001). Higher $\mathrm{H}_{2} \mathrm{O}_{2}$ doses are required at later stages, in which low reactivity compounds with ${ }^{\circ} \mathrm{OH}$ radicals are predominant (Kosaka et al., 2001). It is also important to maintain a low concentration of dissolved $\mathrm{O}_{3}$ for efficient DOC removal, because $\mathrm{O}_{3}$ is required for the rapid formation of ${ }^{\circ} \mathrm{OH}$ radicals (Kosaka et al., 2001). Once $\mathrm{H}_{2} \mathrm{O}_{2}$ is completely consumed, the AOP comes to a halt, achieving a similar COD conversion as with pure $\mathrm{O}_{3}$ oxidation (Rivas et al., 2009).

The optimal $\mathrm{H}_{2} \mathrm{O}_{2} / \mathrm{O}_{3}$ ratio depends on the composition of the water solution, such as the type and concentration of the solutes (Kosaka et al., 2001), and the alkalinity of the water (Rosal et al., 2009). In most full-scale plants, the optimal ratio of the $\mathrm{H}_{2} \mathrm{O}_{2}$ dosage to the $\mathrm{O}_{3}$ dosage, appeared to lie between 0.25 and 1.0. There are no formulas available yet for predicting the optimal value, so it should be determined experimentally for each raw water and $\mathrm{O}_{3}$ installation (Acero and von Gunten, 2001). Paillard et al. (1988) determined the optimal conditions for removal of oxalic acid by $\mathrm{O}_{3}+\mathrm{H}_{2} \mathrm{O}_{2}$. Oxalic acid is a major reaction product that accumulates during $\mathrm{O}_{3}$ oxidation of natural waters. The continuous introduction of $\mathrm{H}_{2} \mathrm{O}_{2}$ improved the degradation of oxalic acid, compared to single addition of $\mathrm{H}_{2} \mathrm{O}_{2}$ at the start of the experiment. The optimal 
pH was equal to 7.5 and the optimal dosage of $\mathrm{H}_{2} \mathrm{O}_{2}$ ranged between 0.6 and $0.7 \cdot 10^{-4} \mathrm{M}$, for an initial oxalic acid concentration of $2 \cdot 10^{-4} \mathrm{M}$. This corresponded to a ratio of $0.5 \mathrm{~mol} \mathrm{H}_{2} \mathrm{O}_{2}$ consumed per mole $\mathrm{O}_{3}$. The presence of bicarbonates did not influence the optimal conditions, but if the solution contained bicarbonates, a significant reduction of the degradation rate for oxalic acid was observed.

\subsection{A short note on the health hazard of $\mathrm{O}_{3}$ in water treatment}

\subsubsection{Bromate formation}

The formation of the suspected carcinogenic bromate $\left(\mathrm{BrO}_{3}^{-}\right)$ in waters containing $\mathrm{Br}^{-}$is a serious concern in $\mathrm{O}_{3}$ oxidation. $\mathrm{Br}^{-}$is a constituent of all natural waters and its concentration mainly depends on the geochemistry of the watershed (Magazinovic et al., 2004). It ranges from 10 to $1000 \mu \mathrm{g} \mathrm{L}^{-1}$ (von Gunten, 2003b). Currently, the U.S. Environmental Protection Agency (USEPA) and the European Union have set a maximum contaminant level of $10 \mu \mathrm{g} \mathrm{L}^{-1}$ for $\mathrm{BrO}_{3}^{-}$in drinking water (Agus et al., 2009). At $\mathrm{Br}^{-}$concentrations as low as $50 \mu \mathrm{g} \mathrm{L}^{-1}$, excessive $\mathrm{BrO}_{3}^{-}$formation can already become a problem. Details about the formation mechanisms of bromate and strategies to control it can be found in von Gunten, (2003b).

A reduction of the $\mathrm{O}_{3}$ dose by a factor of two could reduce the formation of $\mathrm{BrO}_{3}^{-}$by a factor of more than ten (Meunier et al., 2006). However, the reduction of $\mathrm{O}_{3}$ doses decreases the inactivation of resistant protozoa, such as Cryptosporidium parvum and Giardia lamblia. The lower residual $\mathrm{O}_{3}$ concentration in AOPs and the reduction of $\mathrm{HOBr}$ by $\mathrm{H}_{2} \mathrm{O}_{2}$ reduce $\mathrm{BrO}_{3}^{-}$ formation in $\mathrm{O}_{3}$-based AOPs in comparison to conventional $\mathrm{O}_{3}$ oxidation (von Gunten, 2003b). $\mathrm{BrO}_{3}^{-}$formation is noticeably higher in highly alkaline waters than in waters with lower alkalinity. This is due to the reaction of carbonate radicals with $\mathrm{OBr}^{-}$. Therefore, the application of $\mathrm{O}_{3}$ oxidation has to be carefully evaluated for high-alkalinity waters in order to avoid excessive $\mathrm{BrO}_{3}^{-}$formation (von Gunten, 2003b). Another decisive factor is the temperature of the treated water: $\mathrm{BrO}_{3}^{-}$ formation increases with increasing temperature (von Gunten, 2003b).

\subsubsection{Trihalomethanes and haloacetic acids}

The reaction of NOM with chlorine causes the formation of a variety of potentially carcinogenic DBPs such as THMs and HAAs. The USEPA has currently set maximum contamination levels of total THMs and HAAs at $80 \mu \mathrm{g} \mathrm{L}^{-1}$ and $60 \mu \mathrm{g} \mathrm{L}^{-1}$, respectively. The European Union has only a limit for THMs, namely $100 \mu \mathrm{g} \mathrm{L}^{-1}$ (see Agus et al., 2009 for more details).

The hydrophobic NOM fraction is the main precursor of DBP formation, because it has the highest tendency to react with chlorine (Chang et al., 2002). In Section 4.1, it will be shown that $\mathrm{O}_{3}$ is able to transform these hydrophobic components into hydrophilic products, so that $\mathrm{O}_{3}$ oxidation will decrease the formation potential of THMs and HAAs quite efficiently (Chang et al., 2002; Gallard and von Gunten, 2002; Chin and Bérubé, 2005; Li et al., 2008). Kleiser and Frimmel (2000) and Meunier et al. (2006) found that even a small $\mathrm{O}_{3}$ dose of 1.5 and $2.5 \mathrm{mg}$ per $\mathrm{mg}$ DOC respectively, reduced the THM formation potential by about $70 \%$ in surface water, whereas almost no DOC was removed.

\section{The structural changes of $\mathrm{NOM}$ by $\mathrm{O}_{3}$ oxidation}

NOM fouling is attributed to the accumulation of molecules which are retained on the membrane surface, forming a cake or gel layer, and the adsorption of non-retained molecules in the inner pores of the membrane, leading to constriction and blocking of the inner pores of the membrane. The fouling potential of NOM is defined by different types of chemical and physical interactions between the NOM and the membrane surface, such as hydrophobic interactions, hydrogen bridges and electrostatic interactions, besides the size and conformation of the NOM molecules. NOM fouling in membrane filtration is already reviewed by several authors: Zularisam et al., 2006; Al-Amoudi and Lovitt, 2007; Amy, 2008; Al-Amoudi, 2010; Sutzkover-Gutman et al., 2010. Therefore, this section will only discuss the effect of $\mathrm{O}_{3}$ oxidation on the different fouling mechanisms. A summary of recent studies on the effect of $\mathrm{O}_{3}$ oxidation on membrane fouling, both in surface water applications and municipal wastewater treatment, is given in Table 3.

\subsection{Hydrophobic interactions between NOM and membrane surfaces}

The electrophilic nature of $\mathrm{O}_{3}$ results in the transformation of unsaturated bonds in aromatic moieties, into hydrophilic reaction products, such as carboxylic acids, as stated in the previous section. This could be confirmed by several researchers. Świetlik and Sikorska (2004) treated sand-filtered groundwater with $1.0 \mathrm{mg} \mathrm{O}_{3}$ per $\mathrm{mg} \mathrm{DOC}$, for $10 \mathrm{~min}$, and observed that the hydrophobic DOC (i.e. the DOC fraction retained by the Amberlite XAD 8 resin or a similar resin) decreased from 54 to $5 \%$ of the total DOC. Song et al. (2010) reported that $\mathrm{a} \mathrm{O}_{3}$ dose of $0.5 \mathrm{mg} \mathrm{O}_{3}$ per $\mathrm{mg} \mathrm{DOC}$, applied for $10 \mathrm{~min}$, to surface water, reduced the hydrophobic DOC by $\sim 45 \%$, while the total DOC dropped by only $10 \%$. Van Geluwe et al. (in press) showed that the hydrophobic fraction of the chemical oxygen demand (COD) decreased by $86 \%$, while the overall COD decreased by only $22 \%$, while treating the concentrate stream after NF of surface water, with $2.0 \mathrm{mg}$ $\mathrm{O}_{3}$ per $\mathrm{mg}$ COD for $20 \mathrm{~min}$. The transformation of the hydrophobic part of NOM into hydrophilic reaction products is schematically shown in Fig. 2, where a model structure of a humic acid molecule is drawn, before and after $\mathrm{O}_{3}$ oxidation. Most of the aromatic rings in the humic acid molecule are cleaved by $\mathrm{O}_{3}$, and the molecule is enriched in oxygenated functional groups. The hydrophilic reaction products have a lower propensity for adsorption on membrane surfaces. This is an important reason for the increase of the membrane flux after $\mathrm{O}_{3}$ oxidation.

\subsection{Molecular size and (dis)aggregation of NOM}

\subsubsection{Results obtained by high-performance size exclusion} chromatography (HPSEC)

The size of NOM is a critical parameter for membrane fouling. The occurrence of different modes of fouling is related to foulants size relative to membrane pore size (Katsoufidou et al., 2005; Huang et al., 2008; Lin et al., 2009). Substances close to 
Table 3 - Experimental results of hybrid ozone-membrane systems.

\begin{tabular}{|c|c|c|c|c|}
\hline Reference & Raw water composition & Oxidation features & Membrane features & Results \\
\hline $\begin{array}{l}\text { Karnik et al. } \\
\text { (2005) }\end{array}$ & $\begin{array}{l}\text { Michigan lake water (US) } \\
\text { pH: } 7.7-8.6 \\
\text { TOC: } 8.6-11.6 \mathrm{mg} \mathrm{L}^{-1} \\
\text { Alkalinity: } 145-157 \mathrm{mg} \mathrm{L}^{-1} \\
\mathrm{CaCO}_{3} \\
\text { UVA }(254 \mathrm{~nm}): 0.160-0.180 \mathrm{~cm}^{-1}\end{array}$ & $\begin{array}{l}\mathrm{C}_{\mathrm{O}_{3}}(\mathrm{~g}): 1-12.5 \mathrm{mg} \mathrm{L}^{-1} \\
\text { Gas flow rate: } 6 \mathrm{~L} \mathrm{~h}^{-1} \\
\text { Batch volume: } 3.5 \mathrm{~L}\end{array}$ & $\begin{array}{l}\mathrm{UF}\left(\mathrm{TiO}_{2}\right) \\
\text { MWCO: } 15 \mathrm{kDa} \\
\text { Constant flux of } \\
1820 \mathrm{~L} \mathrm{~m}^{-2} \mathrm{~h}^{-1} \mathrm{MPa}^{-1} \\
\text { Transmembrane pressure: } \\
17 \mathrm{kPa}\end{array}$ & $\begin{array}{l}\text { Without } \mathrm{O}_{3} \text { treatment, flux reduced } \\
40 \% \text { in } 12 \mathrm{~h} \text {. Stable fluxes of more } \\
\text { than } 95 \% \text { of the pure water flux } \\
\text { can be maintained if the dissolved } \\
\mathrm{O}_{3} \text { concentration at the membrane } \\
\text { surface is greater than } 0.05 \mathrm{mg} \mathrm{L} \mathrm{L}^{-1} \text {. } \\
\text { Continuous } \mathrm{O}_{3} \text { injection was not } \\
\text { necessary. Intermittent } \mathrm{O}_{3} \text { injection for } \\
1 \text { min per } 5 \text { min gave the same results. } \\
\text { Improved permeate flux recovery at } \\
\text { lower pH due to higher dissolved } \mathrm{O}_{3} \\
\text { concentration }\end{array}$ \\
\hline $\begin{array}{l}\text { Kim et al. } \\
\text { (2007) }\end{array}$ & $\begin{array}{l}\text { Sewage water } \\
\text { TOC: } 163 \mathrm{mg} \mathrm{L}^{-1} \\
\text { BOD }_{5}: 85 \mathrm{mg} \mathrm{L}^{-1} \\
\text { Suspended solids: } \\
203 \mathrm{mg} \mathrm{L}^{-1}\end{array}$ & $\begin{array}{l}\mathrm{C}_{\mathrm{O}_{3}} \text { (g): } 58 \mathrm{mg} \mathrm{L} \mathrm{L}^{-1} \\
\text { Gas flow rate: } 2 \text { or } 4 \mathrm{~L} \mathrm{~h}^{-1} \text {, } \\
\text { respectively } \\
\text { Backwashing time (per } 60 \mathrm{~min} \text { ): } \\
2 \text { or } 1 \text { min, respectively }\end{array}$ & $\begin{array}{l}\text { Metallic MF membrane } \\
\text { Mean pore size: } 1 \mu \mathrm{m} \\
\text { Pure water flux: } 5000 \mathrm{~L} \\
\mathrm{~m}^{-2} \mathrm{~h}^{-1} \mathrm{MPa}^{-1} \\
\text { Transmembrane pressure: } \\
50 \mathrm{kPa}\end{array}$ & $\begin{array}{l}\text { The effect of air backwashing and } \mathrm{O}_{3} \\
\text { backwashing on the filtration flux was } \\
\text { compared. The mean membrane flux } \\
\text { (for } 25 \mathrm{~h} \text { filtration) was higher in the } \\
\text { case of } \mathrm{O}_{3} \text { backwashing, i.e. } 60 \mathrm{~L} \mathrm{~m}^{-2} \mathrm{~h}^{-1} \\
\text { instead of } 20 \mathrm{~L} \mathrm{~m}^{-2} \mathrm{~h}^{-1} \text {, in the case of } \\
1 \text { min backwashing per hour, and } \\
75 \mathrm{~L} \mathrm{~m}^{-2} \mathrm{~h}^{-1} \text { instead of } 45 \mathrm{~L} \mathrm{~m}^{-2} \mathrm{~h}^{-1} \text {, } \\
\text { in the case of } 2 \text { min backwashing } \\
\text { per hour }\end{array}$ \\
\hline $\begin{array}{l}\text { Kim et al. } \\
\text { (2008) }\end{array}$ & $\begin{array}{l}\text { Michigan lake water (US) } \\
\text { TOC : } 11.8 \mathrm{mg} \mathrm{L}^{-1}\end{array}$ & $\begin{array}{l}\mathrm{C}_{\mathrm{O}_{3}}(\mathrm{~g}): \\
1.5 / 5.5 / 9.5 \mathrm{mg} \mathrm{L} \\
\text { Gas flow rate: } 12 \mathrm{~L} \mathrm{~h}^{-1}\end{array}$ & $\begin{array}{l}\mathrm{UF}\left(\alpha-\mathrm{Al}_{2} \mathrm{O}_{3}+\mathrm{TiO}_{2}\right) \\
\text { MWCO: } 5 \mathrm{kDa} \\
\text { Pure water flux: } 1430 \mathrm{~L} \mathrm{~m}^{-2} \mathrm{~h}^{-1} \\
\mathrm{MPa}^{-1} \\
\text { Transmembrane pressure: } \\
\text { 68/136/204 kPa }\end{array}$ & $\begin{array}{l}\text { At a gaseous } \mathrm{O}_{3} \text { concentration of } \\
1.5 \mathrm{mg} \mathrm{L}^{-1} \text { : no improvement of } \\
\text { permeate flux, flux reduced to } \\
40 \% \text { of initial value after collecting } \\
1 \mathrm{~L} \text { permeate } \\
\text { At an } \mathrm{O}_{3} \text { concentration of } 5.5 \mathrm{mg} \mathrm{L}^{-1} \text { : } \\
\text { flux reduced to } 75 \% \text { of initial value } \\
\text { after collecting } 1 \mathrm{~L} \text { permeate and } \\
\text { stayed stable afterward } \\
\text { Effect of cross-flow velocity and } \\
\text { transmembrane pressure is illustrated } \\
\text { in Fig. } 6 .\end{array}$ \\
\hline $\begin{array}{l}\text { Lee et al. } \\
\qquad(2005 b)\end{array}$ & $\begin{array}{l}\text { Municipal wastewater, } \\
\text { influent } \\
\text { pH: } 6.8-7.2 \\
\text { TOC: } 8.89-9.91 \mathrm{mg} \mathrm{L}^{-1} \\
\text { COD: } 105-218 \mathrm{mg} \mathrm{L}^{-1} \\
\text { BOD }: 50-86 \mathrm{mg} \mathrm{L}^{-1}\end{array}$ & $\begin{array}{l}\text { For an } \mathrm{O}_{3} \text { dose of } 2.3 \mathrm{mg} \mathrm{L}^{-1} \text {, there } \\
\text { is a residual } \mathrm{O}_{3} \text { concentration of } \\
0.1 \mathrm{mg} \mathrm{L}^{-1} \text { in the permeate }\end{array}$ & $\begin{array}{l}\text { MF (PVDF) } \\
\text { Mean pore size: } 0.22 \mu \mathrm{m} \\
\text { Pure water flux: } 414 \mathrm{~L} \mathrm{~m}^{-2} \mathrm{~h}^{-1}\end{array}$ & $\begin{array}{l}\text { After } 20 \text { min, the flux reduced to } 20 \% \\
\text { of the pure water flux without } \mathrm{O}_{3} \\
\text { pretreatment against } 40 \% \text { with } \mathrm{O}_{3} \\
\text { pretreatment. Due to ozonation, the } \\
\text { thickness of the foulant layer was } \\
\text { reduced by about } 50 \% \text { ( } 1.4 \mu \mathrm{m} \text { instead } \\
\text { of } 3.2 \mu \mathrm{m}) \\
\text { TOC increased through } \mathrm{O}_{3} \text { pretreatment } \\
\text { from } 9.6 \mathrm{mg} \mathrm{L}^{-1} \text { to } 14.5 \mathrm{mg} \mathrm{L}^{-1} \text {. } \\
\text { TOC of permeate with } \mathrm{O}_{3} \text { treatment } \\
\left(15.6 \mathrm{mg} \mathrm{L}^{-1}\right) \text { was higher than without } \\
\mathrm{O}_{3} \text { treatment }\left(12.5 \mathrm{mg} \mathrm{L}^{-1}\right)\end{array}$ \\
\hline
\end{tabular}


Table 3 (continued)

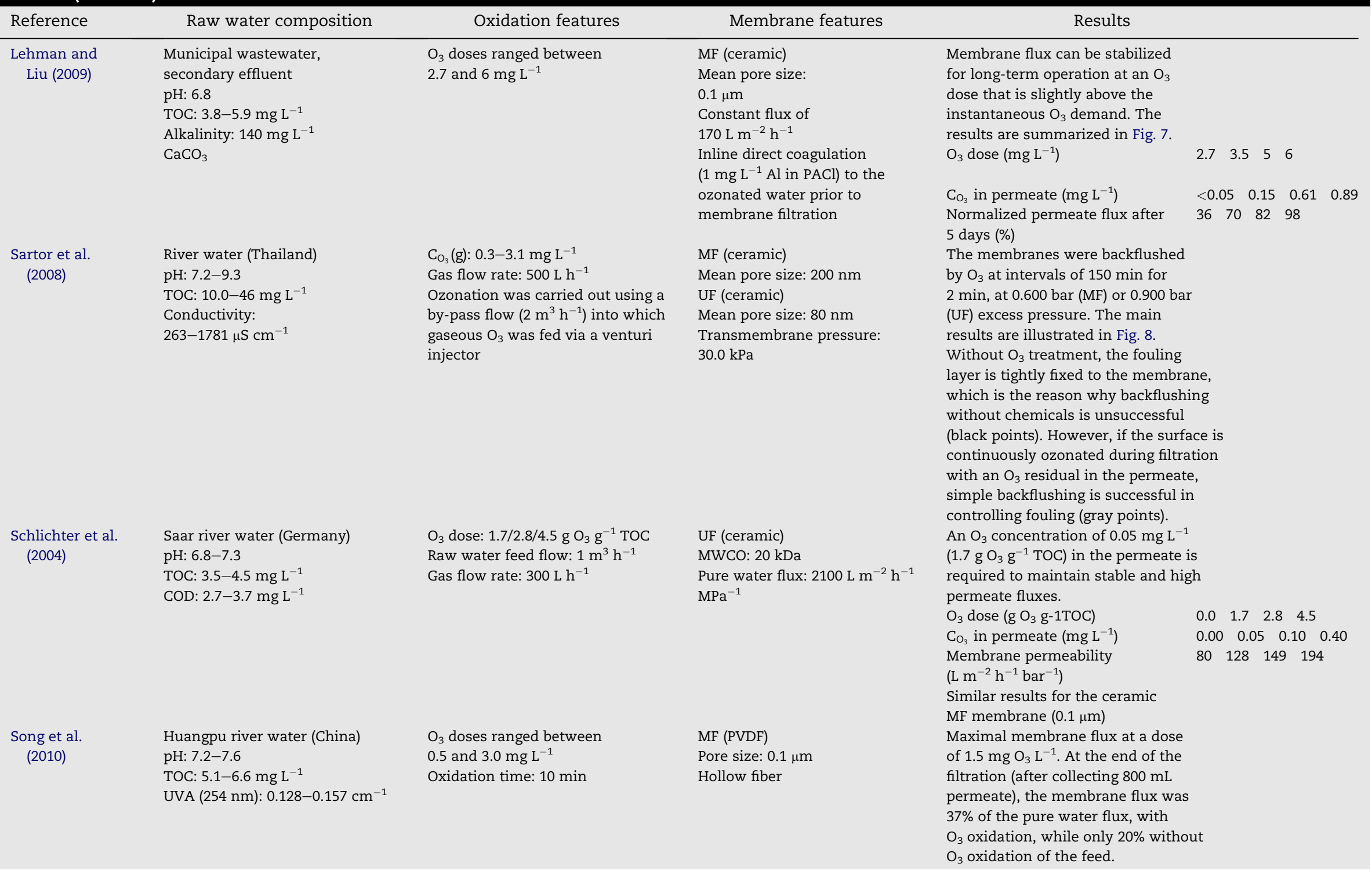



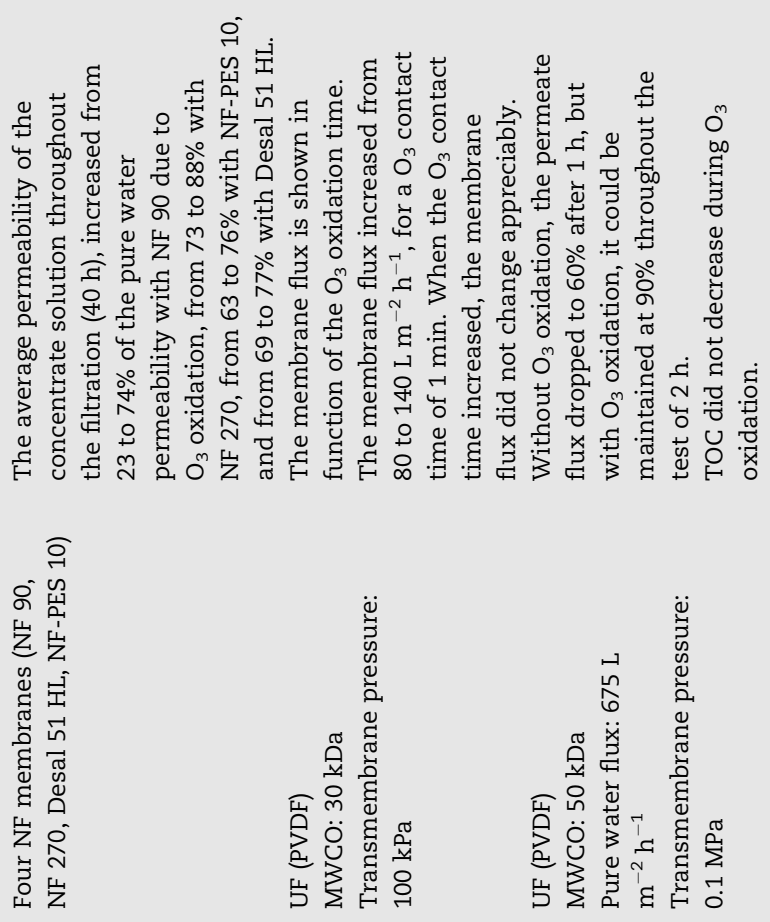
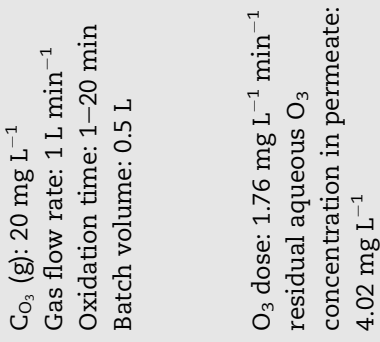

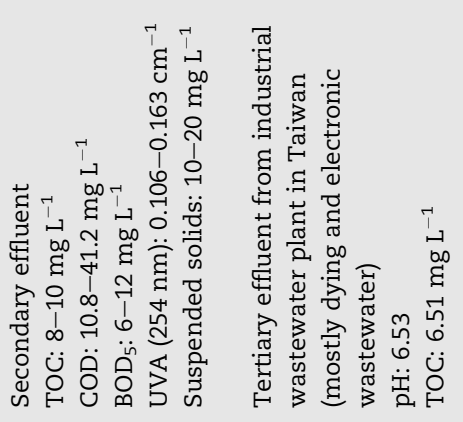

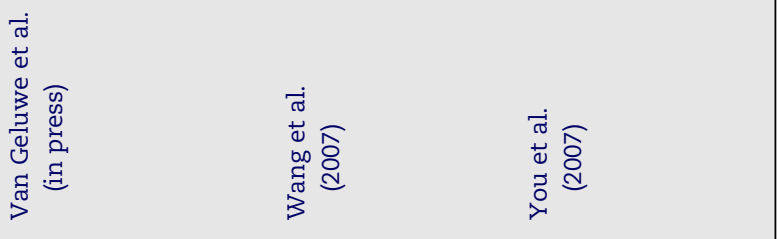

the size of the membrane pores can cause pore blocking, which provokes a severe increase of the filtration resistance (Lohwacharin and Takizawa, 2009). This is the case for the high-molecular mass molecules, such as polysaccharides and proteins, constricting and blocking the pores in loose membranes (MF and UF). Substances much larger than the membrane pores lead to cake formation, that is more readily removed. This is the case for the vast majority of the NOM components with tight membranes (NF and RO). In this case, substances with a high-molecular mass that are retained by the membrane, have a small back diffusion rate during crossflow filtration, so that a thicker cake or gel layer is formed on the membrane surface (Ang et al., 2006).

Various researchers observed that ozonation is able to decompose NOM molecules into smaller fragments. HPSEC analysis before and after ozonation, shows a clear shift toward longer retention times, corresponding to a decrease in the average molecular mass. This is observed for synthetic solution of humic substances (Kerc et al., 2004; These and Reemtsma, 2005; Van Geluwe et al., 2009), as well as for natural waters and wastewater effluents (Nissinen et al., 2001; Nawrocki et al., 2003; Lehman and Liu, 2009; Song et al., 2010). Similar observations were made in studies where the NOM reacted with ${ }^{\circ} \mathrm{OH}$ radicals instead of molecular $\mathrm{O}_{3}$ (Le-Clech et al., 2006; Liu et al., 2008). The cross-flow operation can flush away loose fragments of the cake layer. This decreases the thickness of the foulant layer and thus reduces the flux decline (Karnik et al., 2005; Lee et al., 2005b).

Jansen et al. (2006) investigated the molecular mass distribution of concentrated solutions of humic substances with a low polydispersity (1.23) during $\mathrm{O}_{3}$ oxidation. The average molecular mass shifted from 2600 to $1500 \mathrm{~g} \mathrm{~mol}^{-1}$ and the polydispersity of the peak decreased remarkably from 1.23 to 1.09, after $\mathrm{a} \mathrm{O}_{3}$ consumption of $0.65 \mathrm{~mol} \mathrm{O}_{3}$ per mol C. Another peak emerged at longer retention times, because small compounds were formed during the ozonation process. The size of the reaction products was restricted to only two distinct peaks throughout the reaction. In almost all experiments, the shape of the original peak did not broaden toward longer elution times. This indicates that no random splitting of the humic molecules occurs, since that would result in a very broad range of molecular sizes. Only small molecular fragments are split off from the periphery of the larger humic molecules. The main structure is reduced in size during ozonation, but remains intact. Cleavage occurs mainly at the periphery of the molecules. Steric obstruction related to the coiled structure of the humic substances, prevents $\mathrm{O}_{3}$ and ${ }^{\circ} \mathrm{OH}$ radicals from cleaving bonds in the core of the molecules (Jansen et al., 2007; Nawrocki, 2007).

\subsubsection{Aggregation of humic substances by calcium and magnesium}

The size of the humic substances is also influenced by aggregation/disaggregation forces, which in turn depend on the $\mathrm{pH}$ of the solution. For a long time, humic substances have been regarded as polymeric molecules, having a relatively highmolecular mass. Molecular masses of several 10,000 $\mathrm{g} \mathrm{mol}^{-1}$ have been reported (Sutton and Sposito, 2005). Nowadays, humic substances are regarded as supramolecular associations of many, relatively small $\left(<1000 \mathrm{~g} \mathrm{~mol}^{-1}\right)$ and chemically diverse bio-organic molecules, that are hold together by different kinds of weak interactions, such as Van der Waals forces and hydrogen 
bridges (Piccolo, 2002; Sutton and Sposito, 2005; Ahn et al., 2008). Therefore, it is appropriate to study the aggregation kinetics of humic substances, and the effect of $\mathrm{O}_{3}$ oxidation on it.

Aggregation is promoted by the presence of divalent inorganic cations, such as calcium and magnesium. These ions can bind to carboxylate groups present in certain fractions of the NOM (Hong and Elimelech, 1997; Ahn et al., 2008). Charge screening by the adsorbed cations decreases the net negative charge of the NOM molecules, and thus the electrostatic repulsions with the membrane surface (Engebretson and von Wandruszka, 1998). This phenomena can be observed even at low concentrations of divalent ions, i.e. lower than $0.5 \cdot 10^{-3} \mathrm{M}$ (Shao et al., 2011).

If the concentration of divalent ions is higher than 0.5 . $10^{-3} \mathrm{M}$, these cations act as bridges between carboxylic groups of two adjacent molecules, increasing the attractive forces between them (Shao et al., 2011). This bridging function of divalent cations has been proven with atomic force microscopy (AFM) (Li and Elimelech, 2004; Nguyen and Chen, 2007). This phenomenon was observed for all NOM fractions, but was especially significant in the presence of hydrophobic NOM, i.e. humic substances (Makdissy et al., 2002). Due to the formation of complexes between NOM and divalent ions, the size of the humic aggregates becomes larger (Shao et al., 2011). It is important to note that these conclusions are all obtained without the effect of $\mathrm{O}_{3}$ treatment on NOM. The impact of divalent ions on the complexation of ozonated NOM is not investigated yet, but it is an important issue for further study. An increase of the number of carboxylic acids in NOM after $\mathrm{O}_{3}$ oxidation provides more ligands for complexation, and consequently the negative charge of NOM decreases. A decrease in NOM charge is expected to promote the adsorption of NOM on negatively charged membranes. However, Song et al. (2004) reported that the calcium content of foulants from oxidized surface waters (with $\mathrm{UV}+\mathrm{H}_{2} \mathrm{O}_{2}$ ) is lower than that from raw water $(0.3 \%$ vs. $0.8 \%)$.

Presently, there is little agreement on the effect of complexation on membrane fouling. Shao et al. (2011) stated that the porous character of the flocculated aggregates enhances the permeability of the cake layer formed on the membrane surface, and a smaller flux decline was observed as the calcium concentration increased from 0 to $0.5 \mathrm{mM}$ (see Fig. 9). The aggregate porosity $\left(\epsilon_{\mathrm{agg}}\right)$ is related to the primary particle radius $\left(r_{\text {prim }}\right)$, aggregate radius $\left(r_{\text {agg }}\right)$, and the fractal dimension D (Jiang and Logan, 1991):

$\epsilon_{\text {agg }}=1-\left(\frac{r_{\text {agg }}}{r_{\text {prim }}}\right)^{D-3}$

Fractal dimensions are related to the aggregate structure, e.g. $D=3$ for a sphere, $D=2$ for a flat sheet, $D \approx 1.8-2.4$ for typical aggregates (Waite et al., 1999). Indeed, the equation shows that, for any other shape than perfect spheres, the aggregate porosity increases as $r_{\text {agg }} / r_{\text {prim }}$ becomes larger. However, this trend is reversed at higher calcium concentrations (see Fig. 9). Shao et al. (2011) suggested that the higher flux decline is caused by the formation of calcium bridges between the NOM and the membrane surface. This explanation is questionable, because the authors observed the same trend for neutral membranes.

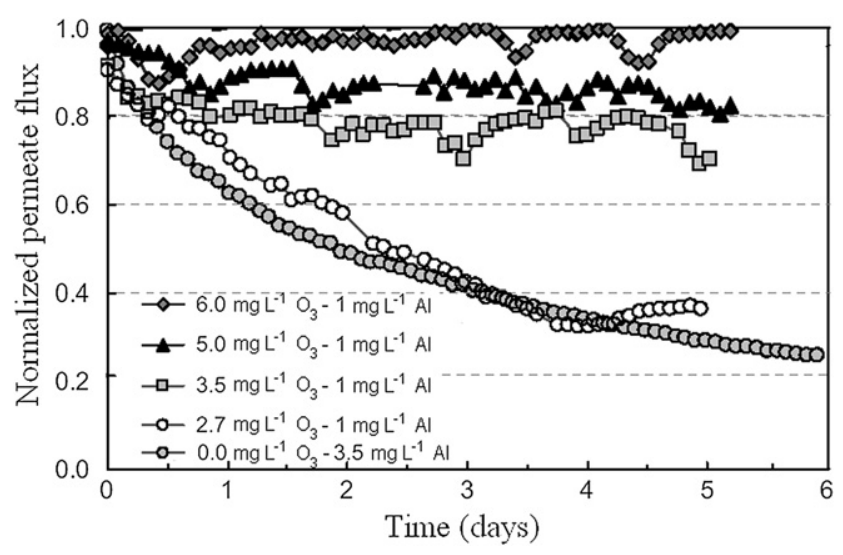

Fig. 7 - Influence of the $\mathrm{O}_{3}$ dose on the flux of a ceramic membrane (nominal pore size: $0.1 \mu \mathrm{m}$ ) treating secondary wastewater effluent. The pure water flux of the membrane is $12,800 \mathrm{~L} \mathrm{~m}^{-2} \mathrm{~h}^{-1} \mathrm{Mpa}^{-1}$. The feed water was ozonated and $1-3.5 \mathrm{mg} \mathrm{L}^{-1} \mathrm{Al}$ of polyaluminiumchloride was added to the ozonated water before it entered the membrane module. Adapted from Lehman and Liu (2009).

In addition, the aggregates can act as a secondary membrane, which removes a significant portion of the small particles, before they reach the polymeric membrane surface. The removal of the small particles prevents the obstruction of membrane pores or the formation of a tightly packed cake layer on the membrane surface (Kuberkar and Davies, 2000). Membrane fouling will be strongly alleviated if NOM aggregation causes a change of the fouling mechanisms, i.e. from internal pore constriction to the formation of a permeable cake on the membrane surface (Lohwacharin and Takizawa, 2009).

Other researchers stated that the complexation causes severe flux decline, because the cross-linked aggregates form a dense, compact cake layer on the membrane surface, with a high fouling resistance (Hong and Elimelech, 1997; Yuan and

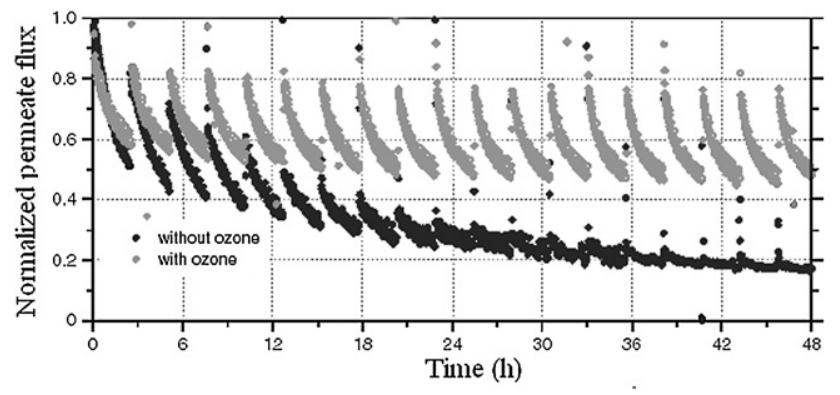

Fig. 8 - Permeate fluxes for a ceramic UF membrane (mean pore size: $80 \mathrm{~nm}$ ) treating surface water. The pure water flux of the membrane is $1600 \mathrm{~L} \mathrm{~m}^{-2} \mathrm{~h}^{-1} \mathrm{MPa}^{-1}$. Fouling is essentially caused by the formation of a biofilm. The membrane flux can be increased considerably by adding $\mathrm{O}_{3}\left(20-100 \mathrm{mg} \mathrm{L}^{-1} \mathrm{O}_{3}\right)$ prior to the membrane module. The suction pressure is $30.0 \mathrm{kPa}$. Membrane fouling can be largely removed with each backflushing cycling (gray points), in contrast to the case without $\mathrm{O}_{3}$ pretreatment (black points). Adapted from Sartor et al. (2008). 


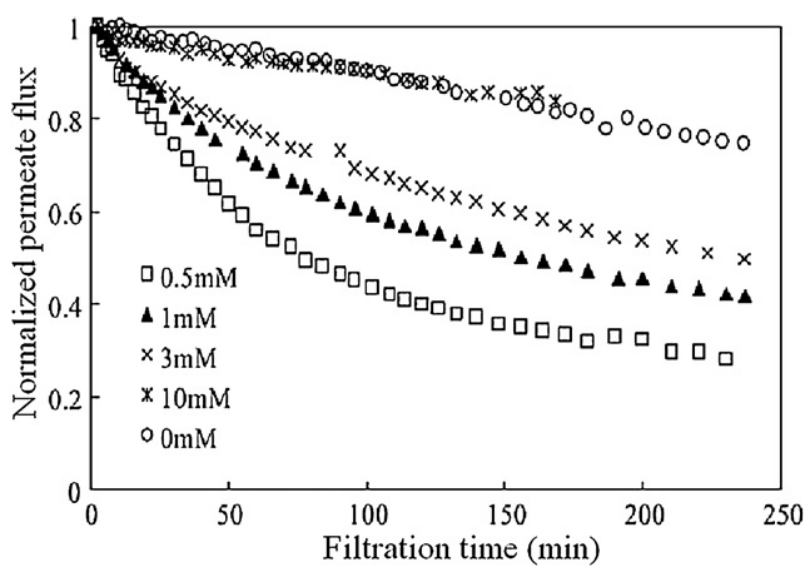

Fig. 9 - Influence of the calcium concentration on the membrane flux during filtration of surface water. Adapted from shao et al. (2011).

Zydney, 1999; Cho et al., 1999, 2000; Schäfer et al., 2002; Costa et al., 2006; Tang et al., 2007; Katsoufidou et al., 2008; Mattaraj et al., 2008; Zhu et al., 2010), or internal deposition of aggregates reduces the pore size of the membrane (Aoustin et al., 2001).

\subsection{Electrostatic interactions and hydrogen bridges}

The surface of many membranes carries a negative charge at neutral $\mathrm{pH}$, because of the presence of carboxylic and amine groups (Childress and Elimelech, 1996). Electrostatic repulsions between the negatively charged groups in NOM and the membrane surface decreases the fouling tendency. For instance, Shao et al. (2011) observed a lower flux decline when humic acids were filtered by a charged regenarated cellulose membrane, in comparison to a neutral membrane of the same material.

Due to the absence of ionizable groups in polysaccharides, electrostatic interactions do not play a role for these molecules. Proteins are nearly all negatively charged at neutral $\mathrm{pH}$, because of the preponderance of weakly acid residues in almost all proteins. The isoelectric point (IEP) of natural proteins lies in many cases between 5 and 6 (Scopes, 1994). The presence of carboxylic $\left(\mathrm{pK}_{\mathrm{a}} \sim 3-5\right)$ and phenolic $\left(\mathrm{pK}_{\mathrm{a}} \sim 8-11\right)$ acid groups in humic substances, make them anionic at neutral pH (Buffle, 1991; Milne et al., 2001). The mole fractions of either carboxylic or phenolic sites in humic substances are usually markedly unequal, with carboxylic acids typically dominating (Buffle, 1991). For instance, Suwannee River humic acids contain $7.85 \mathrm{~mol}$ carboxylic groups per kg (dry weight), while only $1.86 \mathrm{~mol}$ phenolic groups per kg (IHSS, 2001).

The number of carbonyl and carboxyl groups increases after $\mathrm{O}_{3}$ oxidation, as stated previously. Carbonyl compounds carry a negative charge at neutral $\mathrm{pH}$, which is repulsed by the negatively charged membrane. However, carboxyl groups can form strong hydrogen bridges with hydrophilic membranes, such as polyamide and regenerated cellulose membranes.

Van Geluwe et al. (in press) recorded Fourier transform infrared (FTIR) spectra of the NF 270 membrane, after $40 \mathrm{~h}$ filtration of concentrated surface water. He observed that carbonyl compounds were able to adsorb onto the membrane, if the solution was treated with $\mathrm{O}_{3}\left(\mathrm{O}_{3}\right.$ dosage: $1.0 \mathrm{mg} \mathrm{O}_{3}$ per mg COD; oxidation time: $10 \mathrm{~min}$ ). However, the membrane had a significant lower fouling rate after $\mathrm{O}_{3}$ oxidation, although the COD of the solution did not decrease. The mean water flux, during the first $40 \mathrm{~h}$ filtration, increased from 73 to $88 \%$ of the pure water flux.

An estimation of the strength of these hydrogen bridges is provided by Nie et al. (2005). They calculated the strength of hydrogen bridges between the carboxyl group (of butyric acid) and methanol, via ab initio methods. The methanol molecule can be considered as an alcoholic group on the membrane surface. Table 4 shows the dissociation energies of several hydrogen bridges, with water as solvent. The notation, $\mathrm{HO}-\mathrm{C}=\mathrm{O}$, represents that the hydroxyl $\mathrm{O}$ atom of the carboxyl group forms a hydrogen bridge with an alcoholic group on the membrane surface.

The strength of the hydrogen bridges is compared to the electrostatic repulsion energy between two negative charges, e.g. a carboxylate group in the NOM and a negative charge on the membrane surface. The calculated hydrogen bridge strengths strongly depend on the specific type of hydrogen bridges. The formation of hydrogen bridges between carboxyl groups and alcoholic groups are all exothermic, with the exception of $\mathrm{HO}-\mathrm{C}=\mathrm{O}$. The hydrogen bridges are relatively weak, and weaker than those formed between water molecules $\left(11 \mathrm{~kJ} \mathrm{~mol}^{-1}\right)$. The strongest hydrogen bridges are formed with the acid hydrogen of the carboxyl group $(\mathrm{HO}-\mathrm{C}=\mathrm{O})$. This type of bond does not occur frequently at neutral $\mathrm{pH}$, because most

Table 4 - Dissociation energies, bond lengths and the distance dependence of the dissociation energies, for hydrogen bridges and electrostatic bonds of a COOH group in water. Adapted from Nie et al. (2005).

Dissociation energy in water $\left(\mathrm{kJ} \mathrm{mol}^{-1}\right)$

$$
\begin{aligned}
& \text { No interaction } \\
& \text { Type of } \mathrm{H} \text { bridge } \\
& \mathrm{HO}-\mathrm{C}=\mathrm{O} \\
& \mathrm{HO}-\mathrm{C}=\mathrm{O} \\
& \mathrm{HO}-\mathrm{C}=\mathrm{O} \\
& \mathrm{HO}-\mathrm{C}=\mathrm{O}
\end{aligned}
$$

Electrostatic repulsion

between two elementary charges
Bond length (pm)

$\begin{array}{ll}0 & \text { Infinity } \\ -5.6 & \\ 1.5 & 294 \\ 6.7 & 287 \\ 2.4 \times 2 & 275 \\ 3.9 & 265 / 275 \\ & 275\end{array}$

Dependence of the dissociation energy on the separation distance $r$ 
carboxyl groups are dissociated at this $\mathrm{pH}$. The other hydrogen bridges are weaker than the electrostatic repulsion forces between two elementary negative charges. These results show that the hydrogen bridges between the carboxylate groups in the NOM, formed during $\mathrm{O}_{3}$ oxidation, with the membrane surface are in most cases relatively weak, and are of comparable strength as the electrostatic repulsion forces between charges with the same sign. Whether the increase of the number of carboxylic groups by $\mathrm{O}_{3}$ oxidation promotes the adsorption of NOM on the membrane surface or not, is an open question at this moment, and it would be interesting to study this in the future.

\section{Conclusion}

The electrophilic character of $\mathrm{O}_{3}$ accounts for the fast reaction of $\mathrm{O}_{3}$ molecules with unsaturated bonds. The possible reaction pathways between $\mathrm{NOM}$ and $\mathrm{O}_{3}$ were described within the framework of the SBH model (Staehelin, Bühler, Hoigné). The direct reaction of unsaturated bonds in NOM with $\mathrm{O}_{3}$ can lead to the consumption of $\mathrm{O}_{3}$, or the production of an ozonide ion radical $\left(\mathrm{O}_{3}^{-}\right)$, which decomposes upon protonation into a hydroxyl ( $\left.{ }^{\circ} \mathrm{OH}\right)$ radical. The ${ }^{\circ} \mathrm{OH}$ radical is a strong oxidizing agent that can react with NOM molecules. This is referred to as the indirect oxidation pathway. Although the ${ }^{\circ} \mathrm{OH}$ radical is thought to be an unselective oxidant, it can be regarded as electrophilic oxidant.

These direct reactions between $\mathrm{NOM}$ and $\mathrm{O}_{3}$ control the decomposition of $\mathrm{O}_{3}$ during the initial phase of ozonation $(t<20 \mathrm{~s})$, in which very high amounts of ${ }^{\circ} \mathrm{OH}$ are generated, i.e. the concentration $\mathrm{OH}$ is about $10^{-6}$ to $10^{-8}$ times the concentration of $\mathrm{O}_{3}$, and the presence of radical scavengers does not exert any significant effect on the $\mathrm{O}_{3}$ consumption. During the second phase $(t>20 \mathrm{~s})$, the most reactive moieties of NOM have reacted with $\mathrm{O}_{3}$, so that $\mathrm{O}_{3}$ decomposition is mostly controlled by a radical chain reaction, and the ${ }^{\circ} \mathrm{OH}$ concentration is about ten times lower than during the initial phase. During the second phase, some functional groups in the NOM, such as aromatic rings and primary alcohols (abundant in polysaccharides), act as promoters for the decomposition of $\mathrm{O}_{3}$. Alkyl groups and carboxylic acids act as scavengers of ${ }^{\circ} \mathrm{OH}$ radicals.

Although $\mathrm{O}_{3}$ oxidation without addition of $\mathrm{H}_{2} \mathrm{O}_{2}$ is not considered as an $\mathrm{AOP}$, the concentration of ${ }^{\circ} \mathrm{OH}$ radicals during ozonation of NOM solutions, can be as high as in AOPs at neutral $\mathrm{pH}\left(>>10^{-12} \mathrm{M}\right)$. The contribution of the radical pathway can strongly be enhanced by adding $\mathrm{H}_{2} \mathrm{O}_{2}$ to the solution. The addition of $\mathrm{H}_{2} \mathrm{O}_{2}$ improves the mineralization of the saturated reaction products, mostly carboxylic acids, that are formed during $\mathrm{O}_{3}$ oxidation.

Several researchers proved that the application of $\mathrm{O}_{3}$ oxidation of the feed water prior to membrane filtration, resulted in a significant decrease in membrane fouling, although only a minor DOC removal (10-20\%) could be achieved. This is explained by the fact that $\mathrm{O}_{3}$ causes substantial structural changes to the NOM present in the feed water, of which the most important are:

- An efficient removal of aromatic rings, which decreases the adsorption of NOM by hydrophobic interactions.
- A significant increase of the number of carboxylic functions, which are repelled by the negative membrane surface. These repulsion forces have a comparable strength as the hydrogen bridges that carboxylic groups can form with the membrane surface.

- Decomposition of molecules into smaller fragments, whereby small molecular fragments are split off from the periphery of the larger molecules that remain intact.

- A higher propensity for complexation of humic substances with divalent ions, if the concentration of divalent ions is larger than $0.5 \cdot 10^{-3} \mathrm{M}$. However, it is important to note that this figure is obtained with non-ozonated NOM.

\section{Acknowledgments}

Steven Van Geluwe is grateful to IWT-Vlaanderen (Institute for the Promotion of Innovation by Science and Technology in Flanders) for providing a fellowship.

\section{R E F E R E N C E S}

Acero, J.L., von Gunten, U., 2001. Characterization of oxidation processes: ozonation and the $\mathrm{AOP} \mathrm{O}_{3} / \mathrm{H}_{2} \mathrm{O}_{2}$. J. Am. Water Works Ass 93 (10), 90-100.

Agus, E., Voutchkov, N., Sedlak, D.L., 2009. Disinfection by-products and their potential impact on the quality of water produced by desalination systems: a literature review. Desalination 237, 214-237.

Ahn, W.Y., Kalinichev, A.G., Clark, M.M., 2008. Effects of background cations on the fouling of polyethersulfone membranes by natural organic matter: experimental and molecular modeling study. J. Membr. Sci. 309, 128-140.

Ang, W.S., Lee, S., Elimelech, M., 2006. Chemical and physical aspects of cleaning of organic-fouled reverse osmosis membranes. J. Membr. Sci. 272, 198-210.

Al-Amoudi, A.S., 2010. Factors affecting natural organic matter (NOM) and scaling fouling in NF membranes: a review. Desalination 259, 1-10.

Al-Amoudi, A., Lovitt, R.W., 2007. Fouling strategies and the cleaning system of NF membranes and factors affecting cleaning efficiency. J. Membr. Sci. 303, 4-28.

Amy, G., 2008. Fundamental understanding of organic matter fouling of membranes. Desalination 231, 44-51.

Aoustin, E., Schäfer, A.I., Fane, A.G., Waite, T.D., 2001. Ultrafiltration of natural organic matter. Sep. Purif. Technol. 22-23, 63-78.

Beltrán, F.J., 2004. Ozone Reaction Kinetics for Water and Wastewater Systems. CRC Press, Boca Raton (FL, USA).

Buffle, J., 1991. Complexation Reactions in Aquatic Systems: An Analytical Approach. Ellis Horwood, Chichester (United Kingdom).

Buffle, M.O., von Gunten, U., 2006. Phenols and amine induced $\mathrm{HO}^{*}$ generation during the initial phase of natural water ozonation. Environ. Sci. Technol. 40, 3057-3063.

Buxton, G.V., Greenstock, C.L., Helman, W.P., Ross, A.B., 1988. Critical review of data constants for reactions of hydrated electrons, hydrogen atoms and hydroxyl radicals in aqueous solutions. J. Phys. Chem. Ref. Data 17, 513-886.

Can, Z.S., Gurol, M., 2003. Formaldehyde formation during ozonation of drinking water. Ozone Sci. Engin 25 (1), 41-51.

Cataldo, F., 2003. On the action of ozone on proteins. Polym. Degrad. Stabil. 82, 105-114. 
Chang, C.N., Ma, Y.S., Zing, F.F., 2002. Reducing the formation of disinfection by-products by pre-ozonation. Chemosphere 46 , 21-30.

Childress, A.E., Elimelech, M., 1996. Effect of solution chemistry on the surface charge of polymeric reverse osmosis and nanofiltration membranes. J. Membr. Sci. 119, 253-268.

Chin, A., Bérubé, P.R., 2005. Removal of disinfection by-product precursors with ozone-UV advanced oxidation processes. Water Res. 39, 2136-2144.

Cho, J., Amy, G., Pellegrino, J., 1999. Membrane filtration of natural organic matter: initial comparison of rejection and flux decline characteristics with ultrafiltration and nanofiltration membranes. Water Res. 33, 2517-2526.

Cho, J., Amy, G., Pellegrino, J., 2000. Membrane filtration of natural organic matter: factors and mechanisms affecting rejection and flux decline with charged ultrafiltration (UF) membrane. J. Membr. Sci. 164, 89-110.

Costa, A.R., de Pinho, M.N., Elimelech, M., 2006. Mechanisms of colloidal natural organic matter fouling in ultrafiltration. J. Membr. Sci. 281, 716-725.

Darwish, M.A., Al-Najem, N.M., 2000. Energy consumption by multi-stage flash evaporation and reverse osmosis desalters. Appl. Therm. Eng. 20, 399-416.

de la Rubia, A., Rodríguez, M., León, V.M., Prats, D., 2008. Removal of natural organic matter and THM formation potential by ultraand nanofiltration of surface water. Water Res. 42, 714-722.

Eltawil, M.A., Zhengming, Z., Yuan, L., 2009. A review of renewable energy technologies integrated with desalination systems. Renew. Sust. Energ. Rev. 13, 2245-2262.

Engebretson, R.R., von Wandruszka, R., 1998. Kinetic aspects of cation-enhanced aggregation in aqueous humic acids. Environ. Sci. Technol. 32, 488-493.

Frimmel, F.H., Abbt-Braun, G., Heumann, K.G., Hock, B., Luedemann, H.D., 2002. Refractory Organic Substances in the Environment. Wiley VCH, Weinheim (Germany).

Gallard, H., von Gunten, U., 2002. Chlorination of natural organic matter: kinetics of chlorination and of THM formation. Water Res. 36, 65-74.

Goldstone, J.V., Pullin, M.J., Bertilsson, S., Voelker, B.M., 2002. Reactions of hydroxyl radical with humic substances: bleaching, mineralization and production of bioavailable carbon substrates. Environ. Sci. Technol. 36, 364-372.

Gopalan, S., Savage, P.E., 1994. Reaction mechanisms for phenol oxidation in supercritical water. J. Phys. Chem. Phys. 98, 12646-12652.

Hammes, F., Salhi, E., Köster, O., Kaiser, H.P., Egli, T., von Gunten, U., 2006. Mechanistic and kinetic evaluation of organic disinfection by-product and assimilable organic carbon (AOC) formation during the ozonation of drinking water. Water Res. 40, 2275-2286.

Her, N., Amy, G., McKnight, D., Sohn, J., Yoon, Y., 2003. Characterization of DOM as a function of MW by fluorescence EEM and HPLC-SEC using UVA, DOC and fluorescence detection. Water Res. 37, 4295-4303.

Hong, S., Elimelech, M., 1997. Chemical and physical aspects of natural organic matter (NOM) fouling of nanofiltration membranes. J. Membr. Sci. 132, 159-181.

Hoigné, J., Bader, H., 1983a. Rate constants of reactions of ozone with organic and inorganic compounds in water - I: Nondissociating organic compounds. Water Res. 17, 173-183.

Hoigné, J., Bader, H., 1983b. Rate constants of reactions of ozone with organic and inorganic compounds in water - II: Dissociating organic compounds. Water Res. 17, 185-194.

Huang, H., Spinette, R., O'Melia, C.R., 2008. Direct-flow microfiltration of aquasols: I. Impacts of particle stabilities and size. J. Membr. Sci. 314, 90-100.

I.H.S.S., 2001. Standard and Reference Collection. International Humic Substance Society.
Irabelli, A., Jasim, S., Biswas, N., 2008. Pilot-scale evaluation of ozone vs. peroxone for trihalomethane formation. Ozone Sci. Engin 30, 356-366.

Jansen, S.A., Malaty, M., Nwabara, S., Johnson, E., Ghabbour, E., Davies, G., Varnum, J.M., 1996. Structural modeling in humic acids. Mater. Sci. Eng. C 4, 175-179.

Jansen, R.H.S., Zwijnenburg, A., van der Meer, W.G.J., Wessling, M., 2006. Outside-in trimming of humic substances during ozonation in a membrane contactor. Environ. Sci. Technol. 40, 6460-6465.

Jansen, R.H.S., Zwijnenburg, A., van der Meer, W.G.J., Wessling, M., 2007. Response to comment on "Outside-in trimming of humic substances during ozonation in a membrane contactor". Environ. Sci. Technol. 41, 5162-5164.

Jiang, Q., Logan, B.E., 1991. Fractal dimensions of aggregates determined from steady-state size distributions. Environ. Sci. Technol. 25, 2031-2038.

Karnik, B.S., Davies, S.H.R., Chen, K.C., Jaglowski, D.R., Baumann, M.J., Masten, S.J., 2005. Effects of ozonation on the permeate flux of nanocrystalline ceramic membranes. Water Res. 39, 728-734.

Katsoufidou, K., Yiantsios, S.G., Karabelas, A.J., 2005. A study of ultrafiltration membrane fouling by humic acids and flux recovery by backwashing: experiments and modeling. J. Membr. Sci. 266, 40-50.

Katsoufidou, K., Yiantsios, S.G., Karabelas, A.J., 2008. An experimental study of UF membrane fouling by humic acid and sodium alginate solutions: the effect of backwashing on flux recovery. Desalination 220, 214-227.

Kennedy, M.D., Chun, H.K., Quintanilla Yangali, V.A., Heijman, B. G.J., Schippers, J.C., 2005. Natural organic matter (NOM) fouling of ultrafiltration membranes: fractionation of NOM in surface water and characterisation by LC-OCD. Desalination 178, 73-83.

Kerc, A., Bekbolet, M., Saatci, A.M., 2004. Effects of oxidative treatment techniques on molecular size distribution of humic acids. Water Sci. Technol. 49 (4), 7-12.

Kim, J.O., Jung, J.T., Yeom, I.T., Aoh, G.H., 2007. Effect of fouling reduction by ozone backwashing in a microfiltration system with advanced new membrane material. Desalination 202, 361-368.

Kim, J., Davies, S.H.R., Baumann, M.J., Tarabara, V.V., Masten, S.J., 2008. Effect of ozone dosage and hydrodynamic conditions on the permeate flux in a hybrid ozonation-ceramic ultrafiltration system treating natural waters. J. Membr. Sci. 311, 165-172.

Kimura, K., Amy, G., Drewes, J.E., Heberer, T., Kim, T.U., Watanabe, Y., 2003. Rejection of organic micropollutants (disinfection by-products, endocrine disrupting compounds, and pharmaceutically active compounds) by NF/RO membranes. J. Membr. Sci. 227, 113-121.

Kleiser, G., Frimmel, F.H., 2000. Removal of precursors for disinfection by-products (DBPs) - differences between ozoneand OH-radical-induced oxidation. Sci. Total Environ. 256, $1-9$.

Kosaka, K., Yamada, H., Shishida, K., Echigo, S., Minear, R.A., Tsuno, H., Matsui, S., 2001. Evaluation of the treatment performance of a multistage ozone/hydrogen peroxide process by decomposition by-products. Water Res. 35, 3587-3594.

Košutić, K., Kunst, B., 2002. RO and NF membrane fouling and cleaning and pore size distribution variations. Desalination 150, 113-120.

Kuberkar, V.T., Davies, R.H., 2000. Modeling of fouling reduction by secondary membranes. J. Membr. Sci. 168, 243-258.

Kubicki, J.D., Apitz, S.E., 1999. Models of natural organic matter and interactions with organic contaminants. Org. Geochem. 30, 911-927. 
Kusakabe, K., Aso, S., Hayashi, J.I., Isomura, K., Morooka, S., 1990. Decomposition of humic acid and reduction of trihalomethane formation potential in water by ozone with UV irradiation. Water Res. 24, 781-785.

Lal, M., Schöneich, C., Mönig, J., Asmus, K.D., 1988. Rate constants for the reactions of halogenated organic radicals. Int. J. Radiat. Biol. 54, 773-785.

Le-Clech, P., Lee, E.K., Chen, V., 2006. Hybrid photocatalysis/ membrane treatment for surface waters containing low concentrations of natural organic matters. Water Res. 40, 323-330.

Lee, N., Amy, G., Croué, J.P., Buisson, H., 2004. Identification and understanding of fouling in low-pressure membrane (MF/UF) filtration by natural organic matter (NOM). Water Res. 38, 4511-4523.

Lee, N., Amy, G., Croué, J.P., Buisson, H., 2005a. Morphological analysis of natural organic matter (NOM) fouling of lowpressure membranes (MF/UF). J. Membr. Sci. 261, 7-16.

Lee, S., Lee, K., Mohtar Wan, W., Choi, Y., 2005b. Comparison of membrane permeability and a fouling mechanism by pre-ozonation followed by membrane filtration and residual ozone in membrane cells. Desalination 178, 287-294.

Lee, L.Y., Ng, H.Y., Ong, S.L., Hu, J.Y., Tao, G., Kekre, K., Viswanath, B., Lay, W., Seah, H., 2009. Ozone-biological activated carbon as a pretreatment process for reverse osmosis brine treatment and recovery. Water Res. 43, 3948-3955.

Lehman, S.G., Liu, L., 2009. Application of ceramic membranes with pre-ozonation for treatment of secondary wastewater effluent. Water Res. 43, 2020-2028.

Leiknes, T., 2009. The effect of coupling coagulation and flocculation with membrane filtration in water treatment: a review. J. Environ. Sci. 21, 8-12.

Leppard, G.G., 1997. Colloidal organic fibrils of acid polysaccharides in surface waters: electron-optical characteristics, activities and chemical estimates of abundance. Colloids Surf. A: Physicochem. Eng. Aspects 120, 1-15.

Li, Q., Elimelech, M., 2004. Organic fouling and chemical cleaning of nanofiltration membranes: measurements and mechanisms. Environ. Sci. Technol. 38, 4683-4693.

Li, J., Liu, H., Zhao, X., Qu, J., Liu, R., Ru, J., 2008. Effect of preozonation on the characteristic transformation of fulvic acid and its subsequent trichloromethane formation potential: presence or absence of bicarbonate. Chemosphere 71, 1639-1645.

Liao, C.H., Gurol, M.D., 1995. Chemical oxidation by photolytic decomposition of hydrogen peroxide. Environ. Sci. Technol. 29, 3007-3014.

Lin, C.F., Lin, A.Y.C., Sri Chandana, P., Tsai, C.Y., 2009. Effects of mass retention of dissolved organic matter and membrane pore size on membrane fouling and flux decline. Water Res. 43, 389-394.

Liu, S., Lim, M., Fabris, R., Chow, C., Chiang, K., Drikas, M., Amal, R., 2008. Removal of humic acid using $\mathrm{TiO}_{2}$ photocatalytic process - fractionation and molecular weight characterisation studies. Chemosphere 72, 263-271.

Lohwacharin, J., Takizawa, S., 2009. Effects of nanoparticles on the ultrafiltration of surface water. J. Membr. Sci. 326, 354-362.

Lowe, J., Hossain, Md.M, 2008. Application of ultrafiltration membranes for removal of humic acid from drinking water. Desalination 218, 343-354.

Magazinovic, B., Nicholson, B.C., Mulcahy, D.E., Davey, D.E., 2004. Bromide levels in natural waters: its relationship to levels of both chloride and total dissolved solids and the implications for water treatment. Chemosphere 57, 329-335.

Makdissy, G., Croué, J.P., Amy, G., Lee, N., Habarou, H., Buisson, H, 2002. Advance in the knowledge of the fouling of an ultrafiltration membrane. In: Proceedings of the AWWA Water Quality and Technology Conference, Seattle.

Mao, Y., Schöneich, C., Asmus, K.D., 1991. Identification of organic acids and other intermediates in oxidative degradation of chlorinated ethanes on $\mathrm{TiO}_{2}$ surfaces en route to mineralization. A combined photocatalytic and radiation chemical study. J. Phys. Chem. 95, 10080-10089.

Mattaraj, S., Jarusutthirak, C., Jiraratananon, R., 2008. A combined osmotic pressure and cake filtration model for crossflow nanofiltration of natural organic matter. J. Membr. Sci. 322, 475-483.

McDonald, S., Bishop, A.G., Prenzler, P.D., Robards, K., 2004. Analytical chemistry of freshwater humic substances. Anal. Chim. Acta 527, 105-124.

Meunier, L., Canonica, S., von Gunten, U., 2006. Implications of sequential use of UV and ozone for drinking water quality. Water Res. 40, 1864-1876.

Meylan, S., Hammes, F., Traber, J., Salhi, E., von Gunten, U., Pronk, W., 2007. Permeability of low molecular weight organics through nanofiltration membranes. Water Res. 41, 3968-3976.

Milne, C.J., Kinniburgh, D.G., Tipping, E., 2001. Generic NICA-Donnan model parameters for proton binding by humic substances. Environ. Sci. Technol. 35, 2049-2059.

Nawrocki, J., 2007. Comment on "Outside-in trimming of humic substances during ozonation in a membrane contactor". Environ. Sci. Technol. 41, 5161.

Nawrocki, J., Świetlik, J., Raczyk-Stanisławiak, U., Dąbrowska, A., Biłozor, S., Ilecki, W., 2003. Influence of ozonation conditions on aldehyde and carboxylic acid formation. Ozone Sci. Eng. 25, 53-62.

Nghiem, L.D., Schäfer, A.I., Elimelech, M., 2004. Removal of natural hormones by nanofiltration membranes: Measurement, modeling, and mechanisms. Environ. Sci. Technol. 38, 1888-1896.

Nguyen, T.H., Chen, K.L., 2007. Role of divalent cations in plasmid DNA adsorption to natural organic matter-coated silica surface. Environ. Sci. Technol. 41, 5370-5375.

Nie, B., Stutzman, J., Xie, A., 2005. A vibrational spectral maker for probing the hydrogen-bonding status of protonated Asp and Glu residues. Biophys. J. 88, 2833-2847.

Nissinen, T.K., Miettinen, I.T., Martikainen, P.J., Vartiainen, T., 2001. Molecular size distribution of natural organic matter in raw and drinking waters. Chemosphere 45, 865-873.

Oh, B.S., Park, S.J., Lee, H.G., Kim, K.S., Lee, K.H., Kang, J.W., 2003. Application of ozone/UV process for the reclamation of sewage treatment plant effluent. J. Water Environ. Technol. 1, 141-153.

Ouyang, L., Malaisamy, R., Bruening, M.L., 2008. Multilayer polyelectrolyte films as nanofiltration membranes for separating monovalent and divalent cations. J. Membr. Sci. 310, 76-84.

Paillard, H., Brunet, R., Dore, M., 1988. Optimal conditions for applying an ozone-hydrogen peroxide oxidizing system. Water Res. 22, 91-103.

Pi, Y., Schumacher, J., Jekel, M., 2005. Decomposition of aqueous ozone in the presence of aromatic organic solutes. Water Res. $39,83-88$

Pianta, R., Boller, M., Urfer, D., Chappaz, A., Gmünder, A., 2000. Costs of conventional vs. membrane treatment for karstic spring water. Desalination 131, 245-255.

Piccolo, A., 2002. The supramolecular structure of humic substances. A novel understanding of humus chemistry and implications in soil science. Advan. Agron. 75, 57-134.

Rivas, J., Gimeno, O., Beltrán, F., 2009. Wastewater recycling: application of ozone based treatments to secondary effluents. Chemosphere 74, 854-859. 
Rosal, R., Rodríguez, A., Perdigón-Melón, J.A., Petre, A., GarcíaCalvo, E., 2009. Oxidation of dissolved organic matter in the effluent of a sewage treatment plant using ozone combined with hydrogen peroxide $\left(\mathrm{O}_{3} / \mathrm{H}_{2} \mathrm{O}_{2}\right)$. Chem. Eng. J. 149, 311-318.

Sartor, M., Schlichter, B., Gatjal, H., Mavrov, V., 2008. Demonstration of a new hybrid process for the decentralised drinking and service production from surface water in Thailand. Desalination 222, 528-540.

Schäfer, A.I., Mastrup, M., Lund Jensen, R., 2002. Particle interactions and removal of trace contaminants from water and wastewaters. Desalination 147, 243-250.

Schlichter, B., Mavrov, V., Chmiel, H., 2004. Study of a hybrid process combining ozonation and microfiltration/ ultrafiltration for drinking water production from surface water. Desalination 168, 307-317.

Scopes, R.K., 1994. Protein Purification: Principles and Practice, third ed. Springer Verlag, New York (NY, USA), p. 73.

Seidel, A., Elimelech, M., 2002. Coupling between chemical and physical interactions in natural organic matter (NOM) fouling of nanofiltration membranes: implications for fouling control. J. Membr. Sci. 203, 245-255.

Shao, J., Hou, J., Song, H., 2011. Comparison of humic acid rejection and flux decline during filtration with negatively charged and uncharged ultrafiltration membranes. Water Res. 45, 473-482.

Shon, H.K., Vigneswaran, S., Kim, I.S., Cho, J., Ngo, H.H., 2004. Effect of pretreatment on the fouling of membranes: application in biologically treated sewage effluent. J. Membr. Sci. 234, 111-120.

Siddiqui, M., Amy, G., Ryan, J., Odem, W., 2000. Membranes for the control of natural organic matter from surface waters. Water Res. 34, 3355-3370.

Song, W., Ravindran, V., Koel, B.E., Pirbazari, M., 2004. Nanofiltration of natural organic matter with H2O2/UV pretreatment: fouling alleviation and membrane surface characterization. J. Membrane Sci. 241, 143-160.

Song, W., Ravindran, V., Pirbazari, M., 2008. Process optimization using a kinetic model for the ultraviolet radiation- hydrogen peroxide decomposition of natural and organic compounds in groundwater. Chem. Eng. Sci. 63, 3249-3270.

Song, Y., Dong, B., Gao, N., Xia, S., 2010. Huangpu River water treatment by microfiltration with ozone pretreatment. Desalination 250, 71-75.

Staehelin, J., Hoigné, J., 1982. Decomposition of ozone in water: rate of initiation by hydroxide ions and hydrogen peroxide. Environ. Sci. Technol. 16, 676-681.

Staehelin, J., Hoigné, J., 1985. Decomposition of ozone in water in the presence of organic solutes acting as promoters and inhibitors of radical chain reactions. Environ. Sci. Technol. 19, 1206-1213.

Sutton, R., Sposito, G., 2005. Molecular structure in soil humic substances: the new view. Environ. Sci. Technol. 39, 9009-9015.

Sutzkover-Gutman, I., Hasson, D., Semiat, R., 2010. Humic substances fouling in ultrafiltration processes. Desalination 261, 218-231.

Świetlik, J., Sikorska, E., 2004. Application of fluorescence spectroscopy in the studies of natural organic matter fractions reactivity with chlorine dioxide and ozone. Water Res. 38, 3791-3799.

Tang, C.Y., Kwon, Y.N., Leckie, J.O., 2007. Fouling of reverse osmosis and nanofiltration membranes by humic acid - effects of solution composition and hydrodynamic conditions. J. Membr. Sci. 290, 86-94.

These, A., Reemtsma, T., 2005. Structure-dependent reactivity of low molecular weight fulvic acid molecules during ozonation. Environ. Sci. Technol. 39, 8382-8387.

Thurman, E.M., 1986. Organic Geochemistry of Natural Waters. Martinus Nijhoff Publishers, Dordrecht (The Netherlands.
Van Geluwe, S., Braeken, L., Vinckier, C., Van der Bruggen, B., 2009. Ozonation and perozonation of humic acids in nanofiltration concentrates. Desalin. Water Treat. 6 , 217-221.

Van Geluwe, S., Vinckier, C., Bobu, E., Trandafir, C., Vanelslander, J., Braeken, L., Van der Bruggen, B., 2010. Eightfold increased membrane flux of NF 270 by $\mathrm{O}_{3}$ oxidation of natural humic acids without deteriorated permeate quality. J. Chem. Technol. Biot 85, 1480-1488.

Van Geluwe, S., Vinckier, C., Braeken, L., Van der Bruggen, B. Ozone oxidation of nanofiltration concentrates alleviates membrane fouling in drinking water industry. J. Membr. Sci., in press.

van Voorthuizen, E.M., Ashbolt, N.J., Schäfer, A.I., 2001. Role of hydrophobic and electrostatic interactions for initial enteric virus retention by MF membranes. J. Membr. Sci. 194, 69-79.

Verliefde, A., Cornelissen, E., Amy, G., Van der Bruggen, B., van Dijk, H., 2007. Priority organic micropollutants in water sources in Flanders and the Netherlands and assessment of removal possibilities with nanofiltration. Environ. Pollut. 146, 281-289.

von Gunten, U., 2003a. Ozonation of drinking water: Part I. Oxidation kinetics and product formation. Water Res. 37, 1443-1467.

von Gunten, U., 2003b. Ozonation of drinking water: Part II. Desinfection and by-product formation in presence of bromide, iodide and chlorine. Water Res. 37, 1469-1487.

Waite, T.D., Schäfer, A.I., Fane, A.G., Heuer, A., 1999. Colloidal fouling of ultrafiltration membranes: impact of aggregate structure and size. J. Colloid Interface Sci. 212, 264-274.

Wang, G.S., Pai, S.Y., 2001. Ozonation of dissolved organic matter in biologically treated wastewater effluents. Ozone Sci. Eng. 23, 351-358.

Wang, Y., Hollingsworth, R.I., Kasper, D.L., Kasper, D.L., 1999. Ozonolytic depolymerization of polysaccharides in aqueous solution. Carbohyd. Res. 319, 141-147.

Wang, X., Wang, L., Liu, Y., Duan, W., 2007. Ozonation pretreatment for ultrafiltration of the secondary effluent. J. Membr. Sci. 287, 187-191.

Weinstein, J., Bielski, B.H.J., 1979. Kinetics of the interaction of $\mathrm{HO}_{2}$ and $\mathrm{O}_{2}{ }^{-}$radicals with hydrogen peroxide. The HaberWeiss reaction. J. Am. Chem. Soc. 101, 58-62.

Wert, E.C., Rosario-Ortiz, F.L., Drury, D.D., Snyder, S.A., 2007. Formation of oxidation byproducts from ozonation of wastewater. Water Res. 41, 1481-1490.

Westerhoff, P., Aiken, G., Amy, G., Debroux, J., 1999. Relationships between the structure of natural organic matter and its reactivity towards molecular ozone and hydroxyl radicals. Water Res. 33, 2265-2276.

Williamson, D.G., Cvetanovic, R.J., 1970. Rates of ozone-paraffin reactions in carbon tetrachloride solution. J. Am. Chem. Soc. 92, 2949-2952.

Xie, Y.F., 2004. Desinfection By-products in Drinking Water. Lewis, Boca Raton (FL, USA).

Xiong, F., Legube, B., 1991. Enhancement of radical chain reactions of ozone in water in the presence of an aquatic fulvic acid. Ozone Sci. Eng. 13, 349-363.

Xiong, F., Croué, J.P., Legube, B., 1992. Long-term ozone consumption by aquatic fulvic acids acting as precursors of radical chain reactions. Environ. Sci. Technol. 26, 1059-1064.

Yoon, Y., Westerhoff, P., Snyder, S.A., Wert, E.C., 2006. Nanofiltration and ultrafiltration of endocrine disrupting compounds, pharmaceuticals and personal care products. J. Membr. Sci. 270, 88-100.

You, S.H., Tseng, D.H., Hsu, W.C., 2007. Effect and mechanism of ultrafiltration membrane fouling removal by ozonation. Desalination 202, 224-230. 
Yuan, W., Zydney, A.L., 1999. Humic acid fouling during microfiltration. J. Membrance Sci. 157, 1-12.

Zhang, T., Lu, J., Ma, J., Qiang, Z., 2008. Fluorescence spectroscopic characterization of DOM fractions isolated from a filtered river water after ozonation and catalytic ozonation. Chemosphere 71, 911-921.
Zhu, H., Wen, X., Huang, X., 2010. Membrane organic fouling and the effect of pre-ozonation in microfiltration of secondary effluent organic matter. J. Membr. Sci. 352, 213-221.

Zularisam, A.W., Ismail, A.F., Salim, R., 2006. Behaviours of natural organic matter in membrane filtration for surface water treatment - a review. Desalination 194, 211-213. 